\title{
Public Private Mix Partnership Model Development Tuberculosis Management Services as an Effort to Accelerate Tuberculosis Elimination in Pasuruan City
}

\author{
Ansarul Fahrudda ", Rudy Handoko, Joko Widodo \\ Faculty of Social and Political, Universitas 17 Agustus 1945 Surabaya, Surabaya, Indonesia \\ Email address: \\ ansarul_fahrudda@yahoo.com (A. Fahrudda),rudy@untag-sby.ac.id (R. Handoko), papa.wiedya@gmail.com (J. Widodo) \\ ${ }^{*}$ Corresponding author
}

To cite this article:

Ansarul Fahrudda, Rudy Handoko, Joko Widodo. Public Private Mix Partnership Model Development Tuberculosis Management Services as an Effort to Accelerate Tuberculosis Elimination in Pasuruan City. Journal of Public Policy and Administration.

Vol. 5, No. 3, 2021, pp. 97-116. doi: 10.11648/j.jppa.20210503.15

Received: August 28, 2021; Accepted: September 13, 2021; Published: September 30, 2021

\begin{abstract}
Tuberculosis (TB) is still a public health problem in Indonesia and ranks second in the world. Obstacles in implementation of public policies, the National the TB Control Program, the low number of new cases finding, will hinder TB Elimination 2030. The involvement of the private sector and the community in Pasuruan City has increased the case finding rate in the last three years but has not yet reached the target. The finding of TB patients in Diabetes Mellitus (DM) patients is three times higher than the general population, and the prevalence of TB in DM patients is ten times higher than in nondiabetic patients. The purpose of this study was to analyze the partnership model that was carried out and to develop a model for implementing partnerships: Public-Private Mix (PPM) in Pasuruan City. Methodology with a qualitative study goes through the exploration process understands and obstacles of the implementation model the collaboration of the TB control program. Results of the study that principles of partnership that are carried out are only in trust, equality, mutual benefit, and risk-sharing. Then a partnership the model was developed PPM TDC (TB-DM Collaboration), a strategy development to improve case finding and service quality involving primary, secondary and government-private health facilities by collaborating with TB and DM programs, and implementing the principle of Commitment, Cooperation, Trust, Communication, Quality of service, Dependancy, Adaptability, and Profit. As a conclusion of the partnership model: PPM TDC can be an effort to accelerate the achievement of TB elimination. Suggestions for District/Municipality Governments that have implemented PPM are to evaluate and develop the TDC PPM approach, which has not been able to carry directly out the TDC PPM approach. PPM TDC evaluation is carried out by an integrated monitoring team involving academics, professional organizations and periodically.
\end{abstract}

Keywords: Partnership, Public Private Mix, Tuberculosis, Diabetes

\section{Introduction}

In two decades, there has been a shift in the map of diseases that occurred in Indonesia. In 2010, Indonesia faced different challenges, namely infectious disease health problems experienced a decreasing trend in numbers, but non-communicable disease health problems (NCDs) experienced an increasing trend. This condition causes Indonesia to face a double issue in health. Tuberculosis (TB) is one infectious disease that is still a significant health problem in Indonesia. TB is an infectious disease and, in many cases, deadly caused by various strains of mycobacteria, generally Mycobacterium tuberculosis [27] Based on the measurement of DALYs loss, in 2020 compared to 1990 , it can be seen that for 20 years, there has been a shift in non-communicable diseases, namely stroke. However, some have not experienced changes, namely infectious diseases, Tuberculosis [21]. Tuberculosis is an infectious disease that causes the number one death in Indonesia based on the Household Health Survey (SKRT) conducted in 1995 for all age groups (Ministry of Health RI, 2018). In 2020, Indonesia was ranked second in the world after India as a 
country with a TB burden [17].

The Government of the Republic of Indonesia has made efforts to overcome it through the issuance of public policies that are set by policies that are tiered, comprehensive, and have sensitive indicators, namely: 1) Presidential Regulation Number 67 of 2021 concerning Tuberculosis Control, in which it has been determined that Indonesia will be heading to the Tuberculosis Elimination stage in 2030, where there is a decrease in the incidence of TB to 65 per 100,000 population and a decrease in mortality to 6 per 100,000 population. 2) Presidential Instruction Number 1 of 2017 concerning Community Movement for Healthy Living (GERMAS); 3) Regulation of the Minister of Health of the Republic of Indonesia Number 39 of 2016 concerning Guidelines for the Implementation of the Healthy Indonesia Program; 4) Regulation of the Minister of Health of the Republic of Indonesia Number 67 of 2016 concerning Tuberculosis Management; 5) Government Regulation Number 2 of 2018 concerning Minimum Service Standards (SPM) [22].

The government has made efforts to control TB through public health policies by implementing the National Tuberculosis Control Program, which began in 1992 using the Directly Observed, Treatment Shortcourse or DOTs method, and is still being implemented. Then a strategy has been developed involving the role of the private sector in efforts to control $\mathrm{TB}$ so that in its implementation, it is expected to have an impact on changing the morbidity and mortality rate due to $\mathrm{TB}$. The strategy carried out is a recommendation from $\mathrm{WHO}$ [23].

Public policy in the health sector, according to [7], is a plan that directs investment and implementation design to alleviate suffering, improve health services, and prevent illness. The presence of health policies followed by evaluating health policies has proven to be able to create policy impacts and provide scarce information. The impact of health policy is to produce policy strategies, change the health status of populations or individuals, and apply clinical services. Furthermore, government policy is the essential thing to evaluate the system in the current policy.

In its implementation, the performance achievement of the National TB Control Program is still not good, where one of the two program indicators at the national level, namely the Case Detection Rate (CDR) or the number of new patient discoveries, is still low, while the cure rate is by the target, which is above $85 \%$. Likewise, at the level of East Java Province as the Province with the second rank of TB burden, the achievement of the indicator, namely the CDR in 2019 only reached $66 \%$, did not reach the target, while the target was $83 \%$, while the treatment success rate reached $90 \%$ as targeted, namely $>85 \%$ [24].

From the results of the evaluation of the non-achievement of program indicators, according to [18], the sustainability of the program will have the following implications, namely, 1) Continuing or ending the program, 2) Improving administrative practices and procedures, 3) Adding or reducing implementation strategies and techniques, 4)
Institutionalizing the program elsewhere and 5) Allocating resources to other programs.

However, with the still high morbidity and mortality rates for $\mathrm{TB}$, it is necessary to accelerate efforts to find new $\mathrm{TB}$ patients through a more active discovery strategy, followed by adequate treatment and adding Health Service Facilities (Fasyankes).

Drennan et al. [11] said that for future policy development, policy analysis was carried out to help the government to identify successes, failures and problems that arise. Policy development is divided into three stages, namely a) state law, b) government strategy and planning to mandate health policies and social services and c) mandate local governments for health and social services. Furthermore, from the opinion of [11] for the development of health policies, it is necessary to carry out stages in the form of a) drafting regulations governing public services through Standard Operational Procedures (SPO), b) developing strategies and planning services for TB control programs and c) giving the authority for its implementation to health facilities in terms of responsibility. Responsibility for patients, both in Advanced Health Service Facilities (Hospitals) and Early Level Health Facilities (Puskesmas, Private Clinics).

The involvement of health services needs to be developed in addition to being carried out by government-owned health facilities as well as non-government health facilities; this is by what was conveyed [59], which stated that the implementation of public policy is an action taken by the government and the private sector both individually and in groups - intended to achieve a goal.

The development of public policies in the government and non-government sectors, according to [5], there are 3 (three) factors that need to be considered to achieve public policy goals through a layered administration system, namely:

1) Joining up is how efforts are made so that government and non-government parties create an integration to create problem-solving.

2) Boundary crossing is how to work effectively with parties outside the government who are in contact with policy implementation.

3) Partnership is a relationship between 2 or more parties to work effectively to get the best results.

Then, in addition to involving the private sector, active TB discovery strategies can be carried out in immunosuppressed patients; one of them, according to [64] are uncontrolled Diabetes Mellitus (DM) patients, where these patients have an increase in blood sugar which affects the immune system, making them susceptible to TB infection. The highest estimated number of DM cases in 2000 to 2030 in Indonesia is ranked 4th in 10 countries. This estimate is a significant estimate that deserves the attention of prevention, treatment and public awareness policymakers. DM is a severe chronic disease that occurs when the pancreas does not produce enough insulin (a hormone that regulates blood sugar or glucose) or when the body cannot effectively use the insulin it produces. Based on data from the WHO Global Report (2016), the number of cases and prevalence of diabetes has 
increased over the last few decades. DM is now a significant public health problem, becoming one of the four priority noncommunicable diseases targeted for follow-up by world leaders, including Indonesia. There is a trend of increasing DM prevalence except for East Nusa Tenggara Province, which has decreased prevalence.

TB and DM both become health problems that need national government attention. $\mathrm{TB}$ is classified as an infectious disease, while DM is classified as a noncommunicable disease. Still, it can happen to one person because people with DM have lower immunity, so they are more at risk of contracting infectious diseases. DM is a risk factor for TB that can affect the existence of response and response to treatment. Pulmonary TB is difficult to heal in the presence of uncontrolled DM [43].

In addition to developing health facilities by involving the non-government sector, according to [63], a collaboration of health care programs needs to be done to achieve better results where all available resources can create efficiency. The TB control program requires collaboration with cross-programs that are closely related, in this case, the DM control program with the support of structured policies. Of course, the success of collaborative TB-DM programs will have an impact on accelerating the reduction in morbidity and mortality, which will further reduce losses, where for developing countries, deaths caused by TB are $25 \%$ of all deaths and around $75 \%$ of TB patients are of productive age, according to [52], a TB patient will lose between $38 \%$ to $70 \%$ of his income per year. Then for DM, based on data from the Social Security Administering Agency (BPJS), there are 5 (five) diseases with the highest burden of hospitalization of non-communicable illnesses where DM is in the first place [20].

From the things above, it is necessary to develop a partnership development model for TB control programs and collaborative public services as the embodiment of the state providing guarantees to all citizens to get access to quality health services and provide easy access to services in the context of accelerating the achievement of the national TB control program targets, namely elimination by 2030 .

Public policies have been set by the Government of the Republic of Indonesia through Government Regulations, Regulations of the Minister of Health, to tackle TB disease, including the stipulation of $\mathrm{TB}$ as a Minimum Service Standard in the health sector for Regency and City Governments, so that all existing regencies/cities must implement TB control programs. However, one of the performance indicators that was not achieved was that the discovery of new TB cases was still less than the WHO target, namely $>70 \%$ of patients were found among the estimated number of morbidity rates that had been determined, so this would result in hampering the achievement of TB elimination. Efforts to accelerate the discovery of new TB patients have been carried out by the government involving the private sector through the PPM Partnership model. Based on data from the Integrated Tuberculosis Information System (SITT) of East Java Province, from one of the regencies and cities in East Java Province, namely Pasuruan City, which has implemented the PPM partnership model, the number of new TB patients being treated has continued to increase over the last three years. However, it is still have not reached the target. As the formulation of the problem, namely:

1) How is implementing the TB control program with the Public-Private Mix partnership model in Pasuruan City?

2) How to develop a Public-Private Mix partnership model for the Tuberculosis control program to be more effective in accelerating the achievement of TB elimination?

Based on the formulation of the research problem, with the scope of a case study of the implementation of the national program policy for TB control in Pasuruan City, the research objectives to be achieved are:

1) Knowing and analyzing the implementation of the partnership model: Public-Private Mix in Pasuruan City to prevent Tuberculosis in Pasuruan City.

2) Formulate and recommend a more effective Public Private Mix partnership model to accelerate the achievement of Tuberculosis Elimination.

The results of this study provide new findings in implementing public policies in the health sector of the national TB control program by developing a partnership model, namely the public-private mix by collaborating with TB-DM, to increase service access in the context of accelerating Indonesia's TB elimination in 2030.

\section{Literature Review}

\subsection{Partnership in Public Service}

Partnership seen from an etymological perspective is adapted from the word partnership and comes from the word partner, translated "partner, mate, ally or companion. Meanwhile, the partnership is translated into partnership or partnership, which is interpreted as a form of partnership between two parties and a sense of mutual need to increase capacity and capability in a particular business field or a specific goal, to obtain good results [52]. [4] Defines the concept of partnership or partnership between the government and the private sector simply as a work arrangement based on reciprocal commitments, over and above those stipulated in each contract, between an organization in the public sector and an organization outside the public sector. The partnership involves a form of cooperation that is more than just a cooperation contract, more intensive and interactive. Each of them has independence and a commitment to realize a common goal. [12] mentions that the background of the birth of the Partnership concept can be seen in community development which tends to provide excellent service. The community demands good service, good quality, good performance and is served by results-oriented officials. Meanwhile, the government's capacity as a service provider seems limited. Therefore, this concept began to be thought of when it was felt that, on the one hand, the resources owned by the government were minimal, while the needs of its citizens were getting bigger, and the government couldn't fulfil them alone. 
According to [39] the partnership is not something new in the development of public administration. Indeed, the Old Public Administration (OPA) approach is not yet known because, in this approach, public organizations are still inward-oriented. The emphasis is more on efficiency, rationality effectiveness, direct handling of services by the government and closing to the outside environment. This is very clear in the mainstream OPA, as stated [12] that public administration is characterized by, among other things, direct services through government agencies, limited public policy and administration in policy making and government administration, service providers are accountable to officials. Elected with little discretion, public programs are run hierarchically, the organization's primary values are efficiency and rationality, and some public organizations operate very efficiently as closed systems with limited citizen involvement. In later developments, in the era of the New Public Management (NPM) approach, partnership theory was noted as part of this approach, where ideas and practices were essentially trying to incorporate the private sector into the public sector [26]. There are four reasons, namely the first, that in the implementation of public services, it seems irrelevant that it only relies on the ability of the government or public organizations. Therefore, general collaborative management is the solution. This concept describes the facilitation processes and their operation in a multiorganizational plan to solve problems that cannot be solved by a single organization alone. The second lies in the changes that occur in a society that takes place so quickly. The information age allows the creation of information networks. These rapid and complex changes required a response that is also fast, anticipatory and needs the support of resources and various other instruments. The third is related to the sluggishness of public organizations in responding to environmental dynamics, which often lead to inefficiency. As a result, these public organizations often fail. This is in line with [12] statement that the government system develops slowly. The bureaucratic system of government is designed to be stable, and this makes it counterproductive. In an information age globally competitive and rapidly changing today, strategies that cannot change are bound to fail. Then the fourth lies in the tendency of the development of multicultural organizations. According to [30] this tendency is characterized by developing organizations with different cultures, widespread multi-stakeholder participation in organizations, and broader organizational responsibilities. In such conditions, this often encourages the establishment of Hybrid Organizations. This organization can crystallize partnerships or intensive or cohesive cooperation between two or more organizations [39].

The choice of a partnership approach in public services is necessary for the future because this approach has shown several advantages over the public service approach with a single actor. According to [13] these actors build various partnerships, which enable solutions that a single player cannot provide. These partnerships provide the necessary technical, scientific, regulatory, social and economical solutions, which support various projects worldwide.

According to [16] the partnership can refer to various practices of close organizational relationships, cultural types and situationally specific. They are dynamic and encompass each other's agreed goals, a shared sense of responsibility, mutual engagement, understanding, and making use of the different but complementary resources of each partner.

One of these partnership concepts refers to the arrangement between the government and the private sector. [47] stated that this partnership is an arrangement between the government and the private sector. The private sector carries out some or traditionally public activities. Then according to [6] it is stated that partnership is a joint commitment, where all parties have the right and obligation to participate and will be affected equally by the benefits and losses arising from the partnership. From the partnership concepts mentioned above, the partnership in the form of a relationship between parties, the government and the private sector or between the private sector itself, which is built on the basis of mutual, trust, openness, risk sharing and reward sharing, also implies the achievement of more significant results than if something is done without the partnership, joint, trust, risk sharing, reward sharing.

The government and private sector partnership are the Public-Private Partnership (PPP), according to [11] is a longterm arrangement signed by a government or public institution, on behalf of the public sector and private partners, commercial companies, consortia, non-governmental organizations, religious groups and others, which will be responsible for managing part or all of the infrastructure. According to [54] PPP is a form of long-term agreement between the private sector and government institutions that usually aims to utilize personal resources and expertise to provide and deliver public services.

According to [5] using the term PPP is synonymous with cooperation by defining technology programs as publicprivate initiatives involving government with industry and often universities that sponsor the development and use of technology and improve practices to benefit a particular company measurably.

\subsection{Public-Private Mix (PPM)}

The PPP concept has also been adopted to involve all health care providers in providing TB control standards. This is called the PPM approach to TB control. WHO specifically recommends partnerships or partnerships involving the Public and Private sectors for Communicable Disease control programs that are a world problem, namely PPM for the implementation of TB disease prevention and treatment programs, which involve all relevant health service providers in TB treatment and control. [62] states that the PPM approach is an essential component as a strategy for the final phase of the TB control series. PPM is a comprehensive approach for the systematic involvement of all relevant health care providers in TB control to deliver services according to International Standards for TB treatment and achieve national and global TB control targets. PPM includes 
various collaborative strategies such as the public-private sector, namely between the Central Government, in this case, the Ministry of Health of the Republic of Indonesia CQ. Tuberculosis Control Sub-Directorate and the private, publicpublic sector (between the Central Government and other public sector service providers such as public hospitals, prisons or military health services and social security organizations), and private-private collaboration (between NGOs or private hospitals and providers environmental private).

After conducting a review of PPM in 16 developing countries, Lei, X. et al. [28] found that the PPM program has several characteristics in common, as shown in Figure 1.

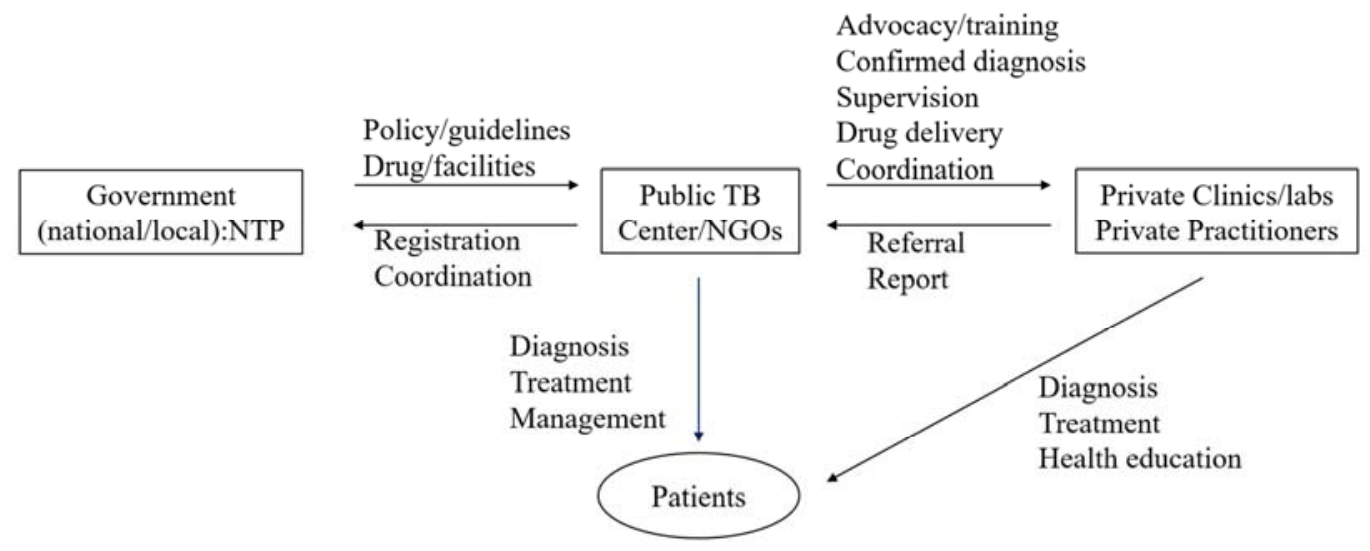

Figure 1. Schematic diagram of a generic PPM Souce: [28].

The Central Government and City Districts have responsibility for policy, regulatory development, planning, financing support, availability of OAT and other supporting logistics and providing facilities. Private health facilities, both institutional and individual, will detect suspected TB cases and then send them to health facilities that have performed standard TB services or report that TB patients have been diagnosed and treated at the private health facilities themselves. Government-owned health facilities, central TB health facilities, and hospitals will receive patient referrals, carry out diagnoses, and then provide treatment or send to private health facilities that send them standardized treatment. There are non-governmental organizations that strengthen the presence of TB service workers. It was added that several PPMs also involved educational institutions in staff training, counselling to patients, technical guidance and evaluation of program results [28].

\subsection{National TB Control Program}

According to Mulyadi [37] implementation is those activities directed toward putting a program into effect or the process of realizing a program to show results. In principle, according to Nugroho [40] the meaning of policy implementation is a way so that a policy can achieve its goals. No more, no less. To implement a public policy, that is, directly implement it in the form of a program or through the formulation of a derivative policy or derivative of the public policy. One of the general policies in the health sector is the National Program for TB control. This program aims to reduce morbidity and mortality due to $\mathrm{TB}$ in the context of achieving health development goals to improve community health status. The target in 2035 there is an $80 \%$ reduction in incidence with a $90 \%$ decrease in mortality compared to 2015. The target of the national TB control program is elimination in 2030 and Indonesia free of TB in 2050.

TB control is all health efforts that prioritize promotive and preventive aspects without neglecting curative and rehabilitative aspects to protect public health, reduce morbidity, disability or death, and decide transmission.

The National Strategy for TB Control consists of: a. strengthening TB program leadership; $b$. increasing access to quality TB services; c. TB risk factor control; d. enhancement of TB partnerships; e. is increasing community independence in TB control; and f. strengthening TB program management. The activities include a. health promotion; $b$. TB surveillance; c. risk factor control; d. discovery and treatment of TB cases; e. is granting immunity; and f. preventive medication.

In providing treatment according to the recommendations from WHO, using the DOTS strategy is direct supervision of short-term treatment with the obligation of every manager of the tuberculosis program to focus attention (direct attention) to find patients with a microscope examination. Then every patient must be observed in swallowing the drug; every drug swallowed by the patient must be in front of a supervisor. Patients must also receive treatment arranged in a management system, distribution with adequate drug supply. Then every patient must receive good medicine, meaning standard short-course treatment that has been clinically proven to work [58].

The main focus of DOTS is patient finding; priority is given to patients with infectious type TB. This strategy can break the chain of TB transmission and is expected to reduce the incidence of TB in the community. Finding and curing patients is the best way to prevent TB disease transmission. The purpose of implementing DOTS is to ensure recovery for patients with pulmonary TB disease, prevent transmission, prevent drug resistance, prevent treatment dropouts and immediately overcome drug side effects if they arise, which 
can reduce morbidity and mortality due to tuberculosis in the world. The DOTS strategy has five components: 1) Political commitment from the government to run the National TB program. 2) Diagnosis of TB through microscopic examination of sputum. 3) Treatment of TB with a combination of Anti Tuberculosis Drugs (OAT), which is directly supervised by the Drug Drinking Supervisor (PMO). 4) OAT supply continuity. 5) Standard recording and reporting to facilitate monitoring and evaluation of $\mathrm{TB}$ control programs. TB Control Activities a. health promotion; b. TB surveillance; c. risk factor control; d. discovery and treatment of TB cases; e. is granting immunity; and $\mathrm{f}$. preventive medication.

TB is a directly infectious disease caused by the TB bacteria, namely Mycobacterium tuberculosis. The majority of TB germs attack the lungs, but TB germs can also attack other organs of the body [61] Tuberculosis, commonly abbreviated as TB, is a chronic disease caused by infection with the Mycobacterium TB complex, transmitted through phlegm (droplets) from TB sufferers to other susceptible individuals [17]. The source of transmission of TB disease is smear-positive TB patients when coughing or sneezing. Patients spread germs into the air in the form of droplets (splashes of phlegm). Droplets containing germs can survive in the air at room temperature for several hours. People can become infected if the droplets are inhaled into the respiratory tract. After the Tuberculosis germs enter the human body through breathing, the Tuberculosis germs can spread from the lungs to other body parts through the circulatory system, respiratory tract, or direct spread to other body parts. The power of transmission is determined by the number of germs that are removed from his lungs. The higher the positive degree of sputum examination results, the more infectious the patient is. If the results of the sputum examination are negative (no visible germs), then the patient is considered non-infectious. Pulmonary TB usually does not show any characteristic signs and symptoms. Usually, the complaints that arise are: a. Fever lasts more than a month, usually in the morning. b. Cough occurs due to irritation of the bronchi; this cough removes/removes the production of inflammation, starting from a dry cough to a purulent cough (producing sputum) c. Shortness of breath occurs when it is advanced where the infiltration of inflammation to half the lung $\mathrm{d}$-chest pain. Chest pain is rarely found; pain occurs when the inflammatory infiltrate reaches the pleura, causing pleurisy. e. Malaise was found in the form of anorexia, weight loss, headaches, muscle aches and night sweats [41].

TB disease has a relationship with vulnerable groups with DM sufferers. Research on the relationship between TB patients and DM patients has been carried out in various developing countries such as Asia, where the prevalence of $\mathrm{TB}$ is twice as significant in DM patients as in the general population. In Bangladesh, the incidence of $\mathrm{TB}$ disease is twice that of the general population. In Yunnan, China, it was shown that TB diagnoses in people with DM were three times higher than in the general population. In Pakistan, it is stated that the prevalence of TB disease in DM patients is ten times higher than in patients without diabetes [65]. In Taiwan, several factors cause $\mathrm{TB}$ in $\mathrm{DM}$ patients, namely poor glycemic control with a risk of 2.21 , age $(<65$ years with a risk of 3.38), female sex with a risk of 2.6 times greater than men. - men and BMI $>25 \mathrm{~kg} / \mathrm{m}^{2}$ have a risk of 2.57 Times (Lee et al., 2016). In Nepal, there are several risk factors for the incidence of TB in DM patients, one of which is smoking behaviour, drinking behaviour, household income [51]. Research conducted in Mexico TB cases that occur in DM patients. The highest incidence occurs in the 40-60 year age group. The incidence of TB in DM patients also occurs in women and in people who do not have access to social security. In addition, patients with diabetes and malnutrition are also more likely to develop TB infection [9] Research in Ethiopia that the duration of suffering from DM above ten years is a risk factor for the incidence of TB in DM patients with an odds ratio of 9 times. The area of residence is also a risk factor in urban areas having a five times greater risk of developing TB in people with diabetes [2].

The problem of TB in DM patients also occurs in Indonesia. Research conducted by [14] at RSUP Dr M. Djamil Padang found that 29 patients had TB from 748 patients with DM (3.88\%). The male TB-DM patients' prevalence was $58.62 \%$, and $72.4 \%$ occurred at the age of 45-60 years. DM patients with a norm weight body mass index also tend to experience TB as much as 51.7\% [14] Diabetes mellitus is a metabolic disease caused by various etiologies characterized by chronic hyperglycemia and impaired carbohydrate, fat, and protein metabolism resulting from insulin secretion and insulin action. Diabetes is a severe chronic disease that occurs when the pancreas does not produce enough insulin (a hormone that regulates blood glucose regulation) or when the body cannot use the available insulin productively [30]. The relationship between TB and DM, then in implementing the PPM TB partnership method, it is necessary to develop it by collaborating with DM.

\subsection{Collaboration}

Collaboration is a term that is often used to describe a pattern of cooperation links carried out by more than one party. The concept of Collaboration defined is also used to describe a cooperative relationship carried out by certain parties. According to [45] Collaboration means working together or collaborating with other parties; individual actors, groups or organizations work together in several businesses. Almost the same understanding is added by [18]; Collaboration is a form of cooperation, interaction, compromise of several elements related to both individuals, institutions and or parties involved directly and indirectly who receive the consequences and benefits. The values that underlie a collaboration are the same goal, common perception, willingness to process, mutual benefit, honesty, compassion and community-based.

Eitan et al. [13] explains, "Collaboration is the mutual engagement of participants in a coordinated effort to solve a problem together. Collaborative interactions are characterized 
by shared goals, symmetry of structure, and a high degree of negotiation, interactivy, and interdependence." The definition explains that Collaboration is joint involvement in a coordinated effort to solve problems together. Collaborative interaction is characterized by shared goals, asymmetrical structure with a high level of negotiation through interactivity and interdependence.

In collaborative cooperation, the principal-agent relationship does not apply because the cooperation is a collaboration between the principal and the principal $[12,32]$ stated that community change is the primary determinant of collaborative public management. These changes take place not only so quickly but also increasingly complex.

In this study, Collaboration is interpreted as starting from a thought process, coordinated efforts, togetherness, cooperation, sharing tasks, equality, and responsibility. The collaborating parties have the same goal, common perception, willingness to proceed, mutual benefits, honesty: compassion and community-based.

The characteristics of Collaboration, among others, are voluntary. Each party has an equal position. Each also has the autonomy and power to make decisions independently even though they agree to a mutual agreement, and the parties working together have a common goal. Are transformational or have a desire to increase systemic capacity by combining the resources they control. In collaborative Collaboration, each party tries to realize dreams and values that exceed their own goals and values [12].

\section{Method}

This study uses a qualitative approach because the subjects and objects of research have characteristics that cannot be approached by statistical procedures, where the sources of research data are actors involved in the implementation of public policies for TB control programs, both from Regional Apparatus Organizations, health facilities, and other institutions that have a relationship. Then the respondents as research sources will provide answers in the form of text, narration, and numbers as qualitative data to the questions of what, how and why of a phenomenon under study and its characteristics will be described. According to [8] qualitative research is a process of exploring and understanding where the behavior of individuals and groups relates to social problems or humanitarian problems. The research process includes making research questions and procedures that are still tentative, collecting data in participant settings, analyzing data inductively, building partial data into themes, and then providing interpretations of the meaning of the data. The final activity is to make reports into a flexible structure.

In its application, according to [57], qualitative research is in line with the need to formulate research problems firmly and unambiguously, explore various possibilities that cause pain, identify intervention strategies and develop potential interventions and evaluate an intervention or program.

According to [36] indicators of qualitative research develop or change according to the nature of the qualitative approach that is flexible, flexible to follow an empirical mindset where everything in this research is determined by the final results of data collection that reflect the actual situation in the field. With the clarity of this indicator, researchers can make more informed decisions about which data will be collected/used.

Based on this, the indicators in this qualitative research are the implementation of public policies on TB control by Law No. 36 of 2009 concerning Health, Presidential Regulation No. 67 of 2021 concerning Tuberculosis Control, Presidential Instruction No. 1 of 2017 concerning Community Movement for Healthy Living (GERMAS). and the Regulation of the Minister of Health of the Republic of Indonesia Number 67 of 2016 concerning Tuberculosis Management of the implementation of the TB control program in Pasuruan City, by emphasizing the extent to which the PPM-KTDM Partnership model can accelerate the achievement of TB elimination in Indonesia by 2030 .

The TB control program in Pasuruan City, East Java Province, by knowing more about the Implementation of TB Control Program Policies, Private Sector Partnerships, and TB-DM Collaboration. As informants of this research are actors who have main tasks that are directly related to implementation and core implementers, include Head of Service, Head of Disease Control, Head of Communicable Disease Control Section, Head of Non-Communicable Disease Control Section, Deputy TB Supervisor from Pasuruan City Health, Director of government and private hospitals, doctors in charge of TB programs in government hospitals and all private hospitals, doctors in order of DM control programs in government hospitals and private hospitals, TB program managers and DM program managers in government hospitals, doctors in private practice with TB patients, then the Head, TB Program coordinator, DM program coordinator at the Puskesmas, and NGO field coordinator.

They are collecting data through:

1) Depth interview using a structured interview technique with questionnaires and interview instructions made by the researcher. The scope of the discussion is:

a. How is the implementation of the TB control program policy?

b. What factors influence the success of the TB control program.

c. How is the DM control program policy implemented?

d. How is the Partnership concept in the TB-DM control program, addressing that DM patients are a group that is susceptible to contracting $\mathrm{TB}$ and $\mathrm{TB}$ patients who suffer from DM will affect TB cure.

2) Observation, namely observing directly to the implementer of the TB Control Program implementation, at the same time as interviewing with informants, 3) Documentation, techniques are carried out to obtain secondary data which is carried out by collecting data from archives and important documents related to the implementation of program policies and 4) Focus Group Discussions, data collection techniques in groups by 
optimizing interactions between participants. Will be used when developing a partnership model: TB-DM collaboration PPM.

Data recorded and recorded is analyzed through a process of simplifying data forms that are easy to read and interpret. Data analysis techniques in this study are as follows: 1) Data Collection is an activity carried out to collect data on research objects that are relevant to the problem formulation and research objectives, 2) Data reduction/processing, at this stage, the data obtained are processed and outlined in the form of detailed and complete descriptions/reports which are then used as a basis for concluding 3) Data Presentation, Presentation is done to make it easier for researchers to see the overall picture or certain parts of this research, data presentation in qualitative form, 4) Conclusion Drawing, Conducted continuously throughout the research process, wherein this conclusion drawing is carried out to understand and get a deep and detailed picture and understanding of a problem so that it will give birth to an inductive conclusion.

\section{Results}

\subsection{Geography and Demographics of Pasuruan City Government}

Pasuruan City is one of 38 regencies/cities in East Java Province located between 112o 45 - 112055 East Longitude and 7o $35^{\prime}-7045$ South Latitude. Its location is on the coast in the north bordering the Madura Strait surrounded by Pasuruan Regency [19], as for the altitude 4 meters above sea level. Administratively, Pasuruan City has an area of +35.29 $\mathrm{km}^{2}$ or $0.07 \%$ of the scope of East Java Province, which is divided into four sub-districts and 34 Kelurahan. The population of Pasuruan City based on BPS data from Pasuruan City is 208.006 residents with details, 104,046 men and 103,960 women. The sex ratio was found to be $100.08 \%$. The average population density is 5,894 people per $/ \mathrm{km}^{2}$. For the number of households as many as 54,009 homes. The Human Development Index in 2020 for Pasuruan City is 75.26. It is ranked number 13 out of 38 Cities in East Java with a Life Expectancy of 71.52 years, Expected Length of Schooling 13.62 years, Average length of schooling 9.12 years, and per capita expenditure of a year 13,281,000 rupiah The life expectancy of Pasuruan, is ranked 24. The type and number of service facilities in Puskesmas are eight units with 29 sub-health centers. For hospitals, there are 2. Namely, one belongs to the Government, RSUD dr. R. Soedarsono, and one private hospital, 16 health clinics, 24 independent/private practice doctors, two health laboratories, two pharmacies, and one blood transfusion service unit. The existence of the Puskesmas as many as eight teams, compared with the existing population, is $1: 26,000$. This figure shows that the number of Puskesmas as the spearhead of health services has met the national target of a maximum of 1:30,000. When added to the number of sub-health centers, it becomes 1:5.621. From the latest health profile, the utilization of health facilities for outpatients in 2019 was 346,973 visits with details of 229,277 people seeking treatment at the Puskesmas and 117,696 seeking treatment at the hospital.
The ratio of visits to first-level health facilities is higher than to hospitals, with a balance of $1.9: 1$, where almost $50 \%$ of patients are referred to hospitals. In addition, there are two types of community-based health service facilities, namely Posyandu (Integrated Service Posts specifically for under five years old) with 297 posts and Posbindu (Integrated Guidance Posts) with 67 Pos. Posbindu is a place for monitoring and early detection of risk factors for noncommunicable diseases managed by the community with a target age of 15 years and over. One of its activities in the early detection of diabetes mellitus. Human resources who provide services consist of 38 specialist doctors, 94 general practitioners, four specialist dentists, 37 dentists, 453 nurses, 216 midwives, 25 nutritionists, and sanitarians. 15, 7 public health personnel, 41 laboratory analysts, 13 Biomedical personnel, 101 pharmacists, including pharmacists. For Health Care Insurance participation registered as participants in the Health Facilities owned by the Pasuruan City Government in 2019 as many as 200,060 or $94.22 \%$.

\subsection{PPM TB Partnership Model for TB Management Program}

The Public Policy of the National TB Control Program has been implemented in Pasuruan City at the same time as the start of this program nationally using the DOTS strategy according to the National Guidelines. The Pasuruan City Health Office is responsible for implementing TB control policies to accelerate the discovery of new TB patients by undertaking a partnership model: PPM, where the partnership model: PPM. The involvement of the private sector is by what was conveyed [59], where it is stated that the implementation of public policy is an action taken by the government and the private sector both individually and in groups intended to achieve goals. There is a classic model, namely the model according [59] which says there are variables that influence public policy, namely implementation activities and inter-organizational communication, characteristics of implementing agents/implementation, economic, social and political conditions, and trends. From implementation. From this opinion, policy implementation runs linearly from public policy, implementor and performance of the public policy.

In implementing the public policy of the National Program for TB Control with the PPM method in Pasuruan City, activities have been carried out such as advocacy, training, treatment services, providing information education to the public, logistics distribution, recording reporting system, referral system, contact investigation, tracking of absent patients. At the same time, the evaluation of process and performance results is not carried out routinely due to limited costs.

The results of interviews and research observations are explained in the implementing organization scheme as the implementer of public policies for the national TB control program in Pasuruan City with the PPM model where health services for TB patients are provided by government health facilities, namely Regional General Hospitals and 
Community Health Centers as well as from non-government parties, namely private sector, namely in the form of private health facilities in the state of hospitals, clinics and individual doctors. In addition, community organizations play an active role in providing non-medical support to TB patients (figure 2).

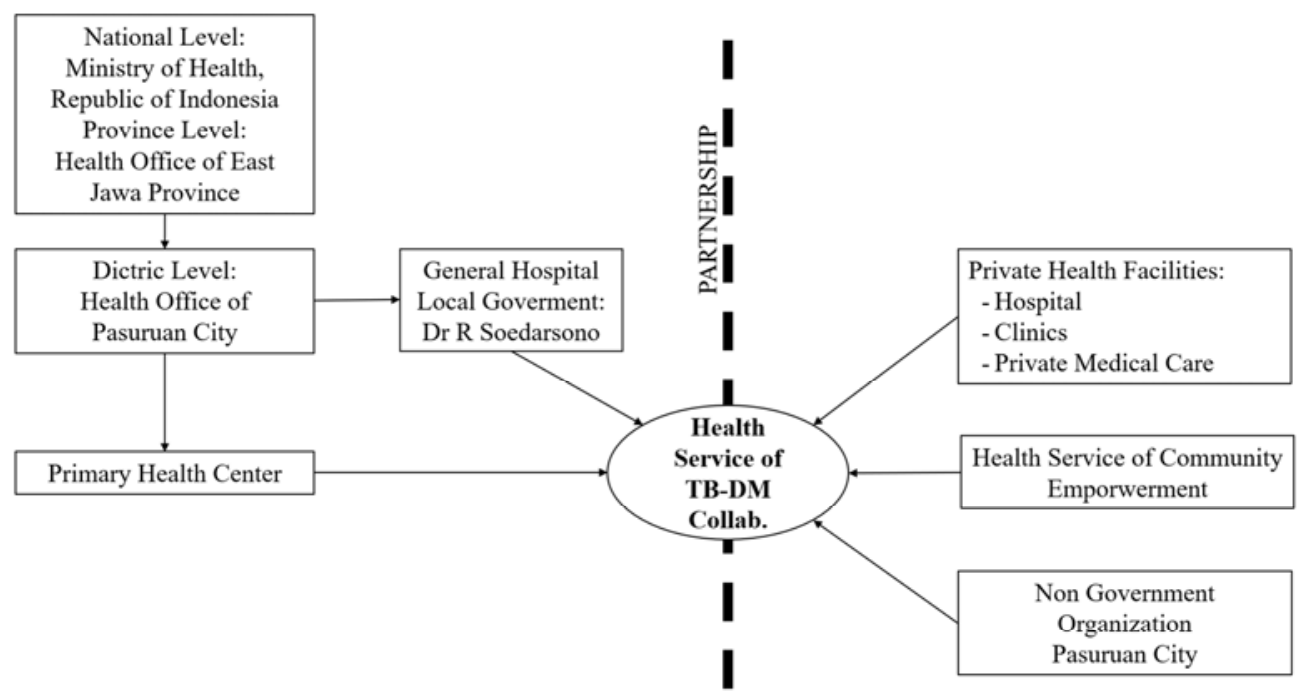

GOVERNMENT

Figure 2. Partnership PPM, Pulblic and Private Sector.

Furthermore, it will be described how the roles and activities of each of the 4 important components, namely Local Government, TB Fasyankes, private Health Services, and Patients, with generic activities in the form of policies or technical instructions, coordination, recording and reporting, advocacy, training, supervision, distribution of OAT, recording of referral reporting, diagnosis, administration of OAT, monitoring of treatment evaluation and counseling (see Figure 3).
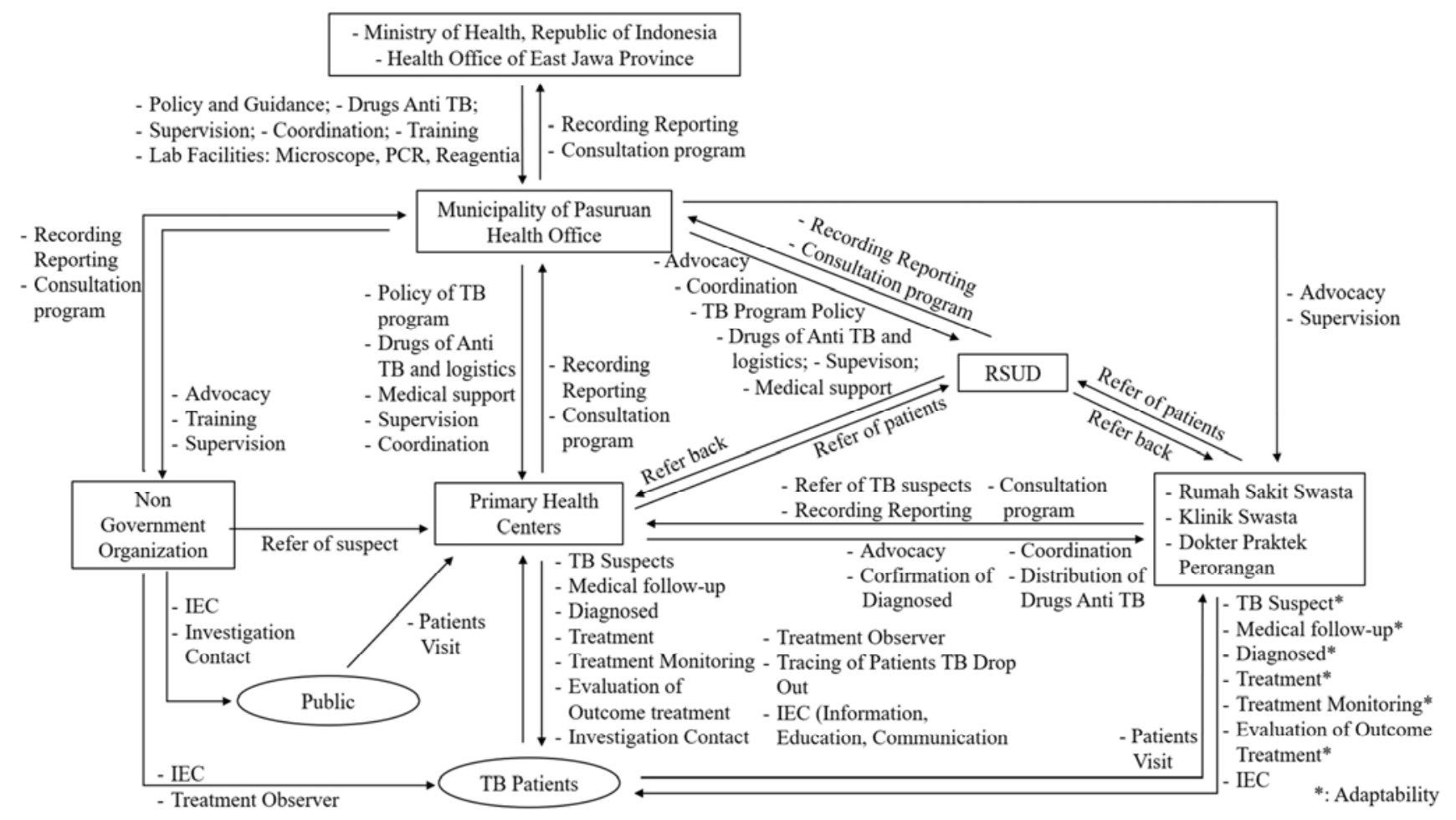

Figure 3. Framework Institution Role of Public Private Mix Tuberculosis in Pasuruan City. 
program regulations as an essential reference for its implementation, by advocating, conducting supervision, sending staff training, distributing OAT and the availability of other supporting logistics to government and private health facilities. Advocacy, especially to community organizations, has led to proposed regulations on TB control in Pasuruan City. For the availability of OAT logistics and support such as reagents so far, there are no obstacles. Staff training facilitated by the Provincial Health Office was by the proposed amount needed. Still, another matter, namely the existing material, not specifically material on the preparation of SOPs according to their duties and conditions of the health facilities, will directly affect the occurrence of obstacles in the implementation of TB services.

The government-owned health facility, namely RSUD dr R Soedarsono, Pasuruan City, has provided TB services in the form of $\mathrm{TB}$ health service activities, including determining suspects, supporting examinations, establishing diagnoses, administering OAT, monitoring taking OAT, evaluating treatment success, receiving referrals for patients with complications, and capacity building. Medical and nonmedical staff to further record and report through SITT version 10.04 to the Pasurunan City Government Health Office to the East Java Provincial Government Health Office to be sent to the Indonesian Ministry of Health.

Other government-owned TB facilities, namely all eight health centres in Pasuruan City, provide TB services in the form of TB health service activities, including determining suspects, supporting examinations, establishing diagnoses, administering OAT, monitoring OAT drinking, evaluating treatment success and the results of these activities are recorded and reported. The Integrated TB Information System version 10.04 to the Pasurunan City Government Health Office to the East Java Provincial Government Health Office to be sent to the Indonesian Ministry of Health. Then, in particular, the Puskesmas conducted TB cadre training, OAT management and reagent logistics, maintenance of laboratory infrastructure, TB education media. In addition, they are coordinating through regular meetings with health facilities and advocating for cross-sectoral, NGO, private health facilities both clinics and individuals, direct guidance through supervision or communication media to health facilities staff.

Puskesmas conduct technical advocacy for the implementation of TB services in private health facilities in the form of hospitals, clinics and individual practices in their operational work areas, then receive referrals from suspected patients, will send the results of supporting examinations sent by private health facilities, as well as send OAT patients to private health facilities which will make a diagnosis and provide treatment. In addition, to coordinate treatment related to personal health facilities.

There are 1 (one) private hospital, 2 (two) private clinics and 2 (two) private practices that have provided TB services. This personal health facility sends suspected TB patients to the nearest government-owned health facility, receives the results of supporting examinations to establish a diagnosis and give OAT, monitor treatment, evaluate treatment success and record reports through SITT and provide counselling to patients.

Specifically for health services for TB patients, the Pasuruan City Health Office responded to PPM by adjusting service activities according to the capabilities of private health facilities, where private health facilities can provide services independently, some have to send patients suspected of having TB found to referral health facilities according to Predefined referral scheme.

Table 1. Adaptibility Health Service, model of Partnership: Public Private Mix Tuberculosis in Pasuruan City.

\begin{tabular}{|c|c|c|c|c|c|c|}
\hline \multirow{2}{*}{ Health Services } & \multicolumn{4}{|l|}{ Private } & \multicolumn{2}{|c|}{ Goverment } \\
\hline & Hospital & Clinics & Medical care 1 & Medical care 2 & Hospital & Primary health center \\
\hline Suspect Finding & $\sqrt{ }$ & $\sqrt{ }$ & $\sqrt{ }$ & $\sqrt{ }$ & $\sqrt{ }$ & $\sqrt{ }$ \\
\hline Medical follow-up & $x$ & $\times$ & $\times$ & $x$ & $\sqrt{ }$ & $\sqrt{ }$ \\
\hline Diagnosed & $\times$ & $\times$ & $\times$ & $\sqrt{ }$ & $\sqrt{ }$ & $\sqrt{ }$ \\
\hline Treatment (Drugs of TB) & $x$ & $x$ & $\times$ & $\sqrt{ }$ & $\sqrt{ }$ & $\sqrt{ }$ \\
\hline Treatment Monitoring & $x$ & $x$ & $x$ & $\sqrt{ }$ & $\sqrt{ }$ & $\sqrt{ }$ \\
\hline Evaluation of Treatment outcome & $\times$ & $\times$ & $\times$ & $\sqrt{ }$ & $\sqrt{ }$ & $\sqrt{ }$ \\
\hline
\end{tabular}

Description: $=$ done; $\times=$ not done.

The TB services in the health facilities consist of 6 types of activities as written in table 1. The types of services provided by the private sector are not all carried out like those carried out by the government-owned health facilities. All private health facilities make suspect findings which will then be sent to the government-owned health facilities for supporting examinations. There are limitations in facilities, namely supporting studies in the form of microscopic examination laboratories or radiological examinations so that if the patient is to be subjected to helping tests, private health facilities will refer to facilities at government health facilities Then based on the results of supporting examinations, a TB diagnosis is enforced; for this, there is a private health facility which in this case is a personal practice doctor who will do it and will then give medicine and monitor the dose of treatment during treatment according to the type of TB the patient is suffering from, and in the end, evaluate the success the therapy. Meanwhile, private hospitals and clinics do not carry out other activities other than finding and sending suspects.

It is a concern of one of the private health facilities, namely from one of the informants of private practice doctors, so that when sending or referring patients suspected of TB to the government health facilities, the receiving health facilities provide feedback so that the sender knows whether the patient has arrived at the targeted health facility and knows 
the progress pain, to create mutual trust.

The existence of an NGO in Pasuruan City, namely Aisyiyah, the Pasuruan City branch, which since 2018 and ends in 2020, has also contributed in the form of accelerating the discovery of suspected patients in the community through contact investigation activities by TB cadres. Suspected patients found are sent to the nearest health centre health facility. In addition, it is encouraging to propose a regulation on TB control in Pasuruan City.

The role of each PPM TB implementer in Pasuruan City above there is something different from the generic PPM scheme presented [63] namely where the training process is carried out by educational institutions, but here the Pasuruan City Health Office appoints and sends staff to take part in the training organized by the East Java Provincial Health Office which is technically carried out by one of the Technical Implementation Units (UPT) specifically for national standard training providers, namely the Murnajati Public Health Training UPT.

Another different thing, namely in the implementation of advocacy apart from the Pasuruan City Health Office, the Puskesmas also made the leaders of private health facilities commit to providing TB services. Then the Puskesmas conducts outreach activities directly to patients as well, not only by private health facilities but also by government health facilities. Likewise, the NGOs involved did not coordinate health partners but as technical implementers of suspect case finding through contact investigation activities by TB cadres and education to the community. PPM in Pasuruan does not involve academic institutions for staff training, patient health education, technical assistance, and outcome evaluation. The difference is only in the implementers who carry out. However, the functions and activities carried out are still the same because they adjust to the existence and limitations of the main tasks of the parts of government institutions, the characteristics of private health facilities, community organizations in Pasuruan City. This adjustment is essential when implementing the partnership model to run and achieve the target.

In addition to the roles and activities of each implementer, communication is a variable that influences the success of public policy implementation. The communication between organizations involved through online and offline media has been running smoothly because there are still few health facilities involved, not all private health facilities are implementing agents, there are only four private health facilities owned by 1 (one) hospital, 2 (two) health clinics and 2 (two) Independent Practitioners. For offline communication, Wasor TB conducts routine supervision of all health facilities implementers to provide assistance and advice to solve problems encountered. There has never been offline communication, which discusses evaluation explicitly as monitoring the partnership implementation process.

For human resources, namely, the officers involved have attended formal training, this has formed the attitude of the implementers who strongly support the activities of this program. According to [61], there is a relationship between
TB training officers and the attitude of the officers. The philosophy is a product of socialization. A person reacts according to the stimulus received; it is impossible to form an attitude before people get information or see the object. Although it is said to precede action, philosophy does not necessarily precede active action but is a predisposition (makes it easier) to act happy or unhappy with particular objects, including cognition, affection and conation components. However, because standard operating procedures have not been made, PPM TB is not implemented correctly, so it is necessary to add training materials on the formulation of SOPs in health facilities according to the students being trained.

The characteristics of the implementers of private health facilities met by researchers are more oriented towards financial gain, so more intensive advocacy is needed. The results of the interview with the informant, one of the private practice doctors in Pasuruan City who started practising in 1991 until now, and this doctor already knows there is a national TB service program, said "I'd better send patients suspected of TB because they don't have supporting examination facilities. and don't treat TB patients, because the medicine has been given free by the government, I don't get anything from treating TB patients", and the doctor did not know that there was a reward that was not in the form of money but got a Professional Credit Unit (SKP) for doctors every year. Provide treatment for TB patients. The granting of the SKP, according to the Deputy Chairperson of PB IDI [42], has become a decision of the professional organization of the Indonesian Doctors Association.

From the results of an interview with the head of a private hospital in Pasuruan City, he said that it would accelerate the fulfilment of suggestions and infrastructure that this year will immediately function while currently sending suspected TB patients to the Puskesmas. By providing comprehensive types of services for TB patients, of course, they will get additional income and include insurance claims.

In the community, they seek and choose treatment to private health facilities because they have characteristics in services and get the needed benefits and are different from government health facilities. The results of research conducted by [46] found that several factors influence the use of private health facilities, namely age, where the most visitors are aged 17 to 60 years, namely $55.2 \%$ where that age is the productive age of the community, then private workers also, insurance ownership other than non-BPJS, distance (access). Meanwhile, for medical purposes, private health facilities receive the most visits to provide treatment for hypertension, diabetes, and TB; hypertension is in first place at $20.4 \%$, followed by diabetes at $4.8 \%$ and pulmonary TB at $2.3 \%$.

The unique characteristics of private hospital health facilities that provide social health services such as TB services from the results of research conducted [15] found that private hospitals can provide quality health services and ease of access with the level of performance of social health services at least as good with government-owned public 
hospitals-according [49], using the PPM method as an effort to maintain the quality of TB treatment services at private health facilities due to limited access for TB patients to come to government-owned health facilities.

There are more visitors for treatment at the governmentowned health facilities than BPJS participation; from 2019 data, 94.22\% of Pasuruan City residents have registered as participants in the Health Care Insurance at the Pasuruan City Government-owned Health Facilities. However, there are still opportunities to seek treatment at private health facilities.

The existence of private health facilities in Pasuruan City, namely 1 (one) hospital, 16 health clinics and 24 independent/private practice doctors, will undoubtedly provide easy access to health services. However, not all of them contribute to the national TB control program; there are still 14 clinics and 22 doctors - private practice.

According to the informants met, related to the social environment, there is still stigmatization of TB patients, especially from neighbours and co-workers. From an economic perspective, the calculation of lost working days due to $\mathrm{TB}$ provides information that $\mathrm{TB}$ in Indonesia is ranked second based on the number of years lost due to all premature deaths and disabilities. Calculations from the IHME in 2019, the average number of lost productive days for TB patients in East Java was 205.91 per 100,000 population or ranging from 142.45 to 289.51 days. As for political support, TIK in the form of regulatory products issued by the legislature, does not yet exist.

From the results of interviews with informants and observations made by researchers, it was found that the implementation of the PPM TB partnership method has fulfilled the principles that must exist in the relationship that occurs between civil society, government and the private sector to achieve a goal including trust, equality, mutual respect. Good, risk-sharing. In this PPM TB partnership model, from the faith of both parties, especially with the private sector, it has been well established, the existence can see it of an operational cooperation script in which there are rights and obligations of each, there is also the availability of materials that must always be there, especially drugs and reagents. For laboratory examinations, and it is clear who provides and distributes them. Then there were mutually beneficial things obtained from each party; the puskesmas increased performance in the TB control program, especially the TB patient discovery rate in its operational area. At the same time, the private sector benefited by increasing the capacity of its health workers in terms of TB, then getting BPJS claims from TB patients being treated. Especially for independent practising doctors, each time they handle TB patients, they will get a reward in the form of a Professional Credit Unit from IDI with the amount depending on the independence of the treatment.

The equality of each first-level health facility, namely Puskesmas, private clinics or private practice doctors at the same level, namely treating TB patients without special conditions and no comorbidities.

Risk sharing is obtained in treating patients who do not want regular treatment and even drop out for treatment, which occurs in the Fayankes of the Government Hospital and the Fayankes of private health facilities. This health facility will contact the puskesmas; then the puskesmas will track the patient to their home and be given the education to continue to seek treatment again. The puskesmas will also contact TB cadres from community organizations to follow patients with chronic treatment problems. In addition, when the primary level health centre or private health facilities receive TB patients with complications, to reduce the risk of treatment failure, a referral process is carried out to the hospital.

From the results of interviews and observations, it was found that the governance carried out in the PPM TB partnership was still not running well, namely mentoring activities through supervision, monitoring of the partnership process and evaluations that were not carried out.

Implementing the Public Policy on health services for the National TB Control Program with the Partnership model in TB PPM that has been implemented provides an output of a cure rate that is above the target and an increase in the discovery of new TB patients still below the target.

The TB PPM carried out in Pasuruan City still has not given maximum results even though there has been an increase in the discovery of new TB patients but has not reached the predetermined target and will undoubtedly affect the national target of TB elimination in 2030 later. Based on data taken from SITT, the achievement of the National TB program performance in Pasuruan City can be seen in table 2 .

Table 2. Number of New Cases Finding and Success Rate of Patients Tuberculosis in Pasuruan City.

\begin{tabular}{llll}
\hline \multirow{2}{*}{ Annual } & \multicolumn{2}{l}{ New Cases Finding and Treatment } & \multirow{2}{\%}{$\begin{array}{l}\text { Success Rate } \\
\text { (target } \mathbf{8 5 \% )}\end{array}$} \\
\cline { 2 - 3 } & Absolut & \% & 83 \\
\hline 2017 & 468 & $73^{*}$ & 89 \\
2018 & 570 & $87^{*}$ & 90 \\
2019 & 582 & $86^{*}$ & \\
\hline
\end{tabular}

* Did not reach the target.

From the results of interviews with informants and observations made by PPM TB, several factors influence, namely not all private health facilities are involved, limited facilities, characteristics of private health facilities which are more oriented to material benefits, partnership management has not gone well, the partnership monitoring process is not carried out., the existing partnership principles have not been fully implemented, and the incomplete contents of the operational cooperation script and TB program are still not a priority program.

\section{Discussion}

Researchers recommend acceleration of the implementation of the National TB Control Program public policy to reach the TB Elimination stage in Indonesia. The performance of the policy strategy section, which initially used the TB PPM Partnership model concept, was developed into the KTD PPM Partnership model. This concept, in 
addition to making improvements to the factors that become obstacles, also needs to be done in collaboration with other health programs that are closely related. From the explanation in the previous chapter, there is a scientific explanation that proves that there are groups at high risk for contracting TB, namely groups with impaired immunity due to changes in body metabolism with impaired insulin production in the body or called people with DM. Several research results have proven the risk relationship between DM patients and TB patients, including it will affect the recovery of TB patients if they suffer from DM. What supports in Indonesia is that the prevalence of DM from year to year has increased.

These two main things have become thoughts for developing the National TB program, which involves the private sector by collaborating with the program for DM. The DM program itself, based on interviews with informants, is still not carried out optimally due to limited facilities, resources and lack of concern from the community. From the observations of researchers, it turns out that there is no cohort recording, where health workers cannot monitor patients who have DM. At the Puskesmas so that the blood sugar levels in his body are controlled. By improving these existing weaknesses, the program's performance will increase the number of new TB patient discoveries and cure rates if you add targets in the form of DM patients and TB patients in government and private health facilities and communitybased health service efforts.

In the PPM KTD, there are 7 (seven) implementer components: the Provincial Health Office, City Health Office, Monitoring Team, government-owned Health Facilities, private Health Facilities, Community-Based Health Facilities, and Community Organizations. In Pasuruan city, there is one government-owned hospital, eight health centres, one private hospital, 16 privately owned health clinics, 24 doctors practising independently/secretly and 67 Posbindu. The scheme of each implementer can be seen in Figure 4.

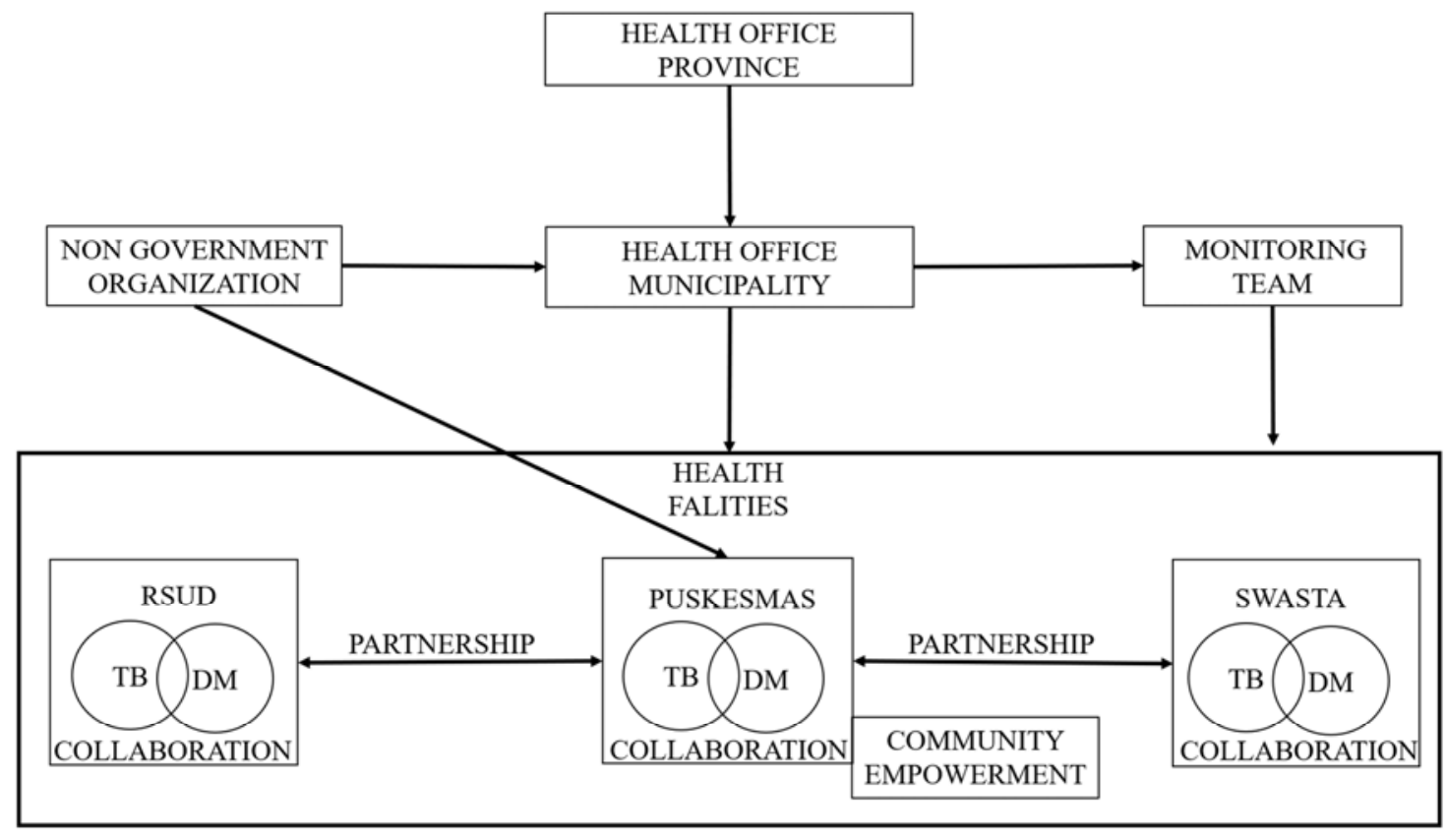

Figure 4. Scheme of Public Private Mix Tuberculosis Diabetes Melitus in Pasuruan City.

From the research results conducted [45] an important key is recommended to strengthen the public sector partnership with the private sector in health services, namely clearly defining the role and coordination of each industry. Then how is the part of the PPM KTD implementer (see Figure 5), it can be explained starting from the Puskesmas Fasyankes, which accepts patients from the community who come for treatment with complaints of illness, especially with complaints that lead to TB or DM, besides that they will also receive referrals from patients and suspected of suffering from TB or DM from Posbindu, a community-based screening activity and community organization in Pasuruan City. Furthermore, the Puskesmas will carry out clinical examinations and laboratory examinations to confirm the diagnosis of TB or DM and provide treatment, track if there are patients who drop out of treatment, conduct close contact investigations and appoint PMO. The Puskesmas also facilitates community organizations in terms of PMO and tracking of DO cases and accepts referrals for suspected TB and DM patients from community organizations.

The Puskesmas will also make referrals for patients with TB or DM cases with medical criteria to a patient referral centre, namely at RSUD Dr R. Soedarsono and received a referral. With private health facilities, the health centre will receive referrals for suspected TB patients and DM patients for examination and diagnosis of TB. The health centre will also send back patients diagnosed with TB and OAT logistics to private health facilities. The types of services provided by private health facilities depend on the available resources. The Puskesmas will record activities, including patient 
medical records and periodically quarterly will report the recapitulation to the Pasuruan City Health Office through the DM collaboration SITT.

Furthermore, the role of the government-owned hospital as the main referral hospital in Pasuruan City is to receive referrals for TB patients with particular conditions both from the Puskesmas and from private health facilities and send back if the patient is in a state that can be treated at the sending health facility according to the decision of the doctor in charge of the patient.
Then for private health facilities to send referrals for TB patients with special conditions, there are complications to the RSUD and receive the return of the referred patients. In addition, it also conducts referrals for suspected TB patients and DM patients to the Puskesmas to make a TB diagnosis; this is done because of the limited types of TB services available at their health facilities and accepts patients who have an established TB diagnosis for further assistance, including being given OAT.

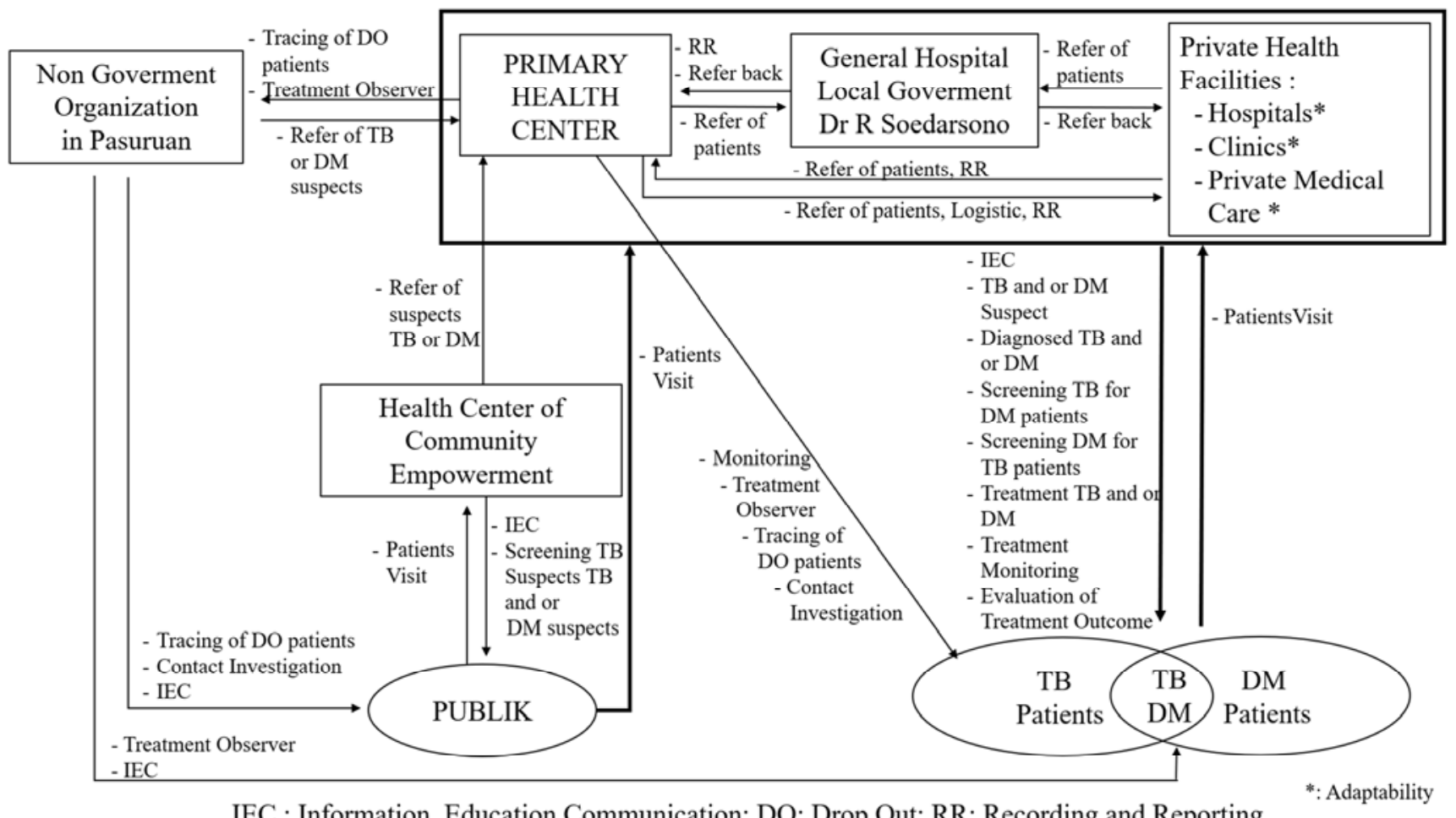

Figure 5. Scheme Framework Health Facilities of Public Private Mix Tuberculosis Diabetes Melitus Collaboration in Pasuruan City.

In general, all health facilities, both government and private, will play a role in receiving patient visits and providing TB services, including IEC, determination of TB and DM suspects, determination of TB and DM diagnoses, TB screening for DM patients, DM screening for TB patients, TB treatment and or DM, monitoring treatment and evaluating treatment outcomes. However, for Puskesmas, there are additional memorable roles, namely tracking when a patient drops out of treatment, contact investigation, monitoring treatment, appointing PMO.

For the partnership of each government and private health facility to run well, the block built in it is collaboration; the researcher suggests using the principles of commitment, cooperation, trust, communication, service quality, dependence, adaptability, and profit.

Commitment is a force that binds individuals to take actions that are relevant to specific goals [35] which is a form of work commitment that appears not only passive loyalty but also involves a dynamic relationship with work organizations that have The goal is to give all efforts for the success of the work organization concerned [42]. Furthermore, according to [53] more emphasis is placed on organizational leaders who must pay attention and be morally responsible for staff job satisfaction because staff job satisfaction is High levels of productivity will have an impact on increasing performance and productivity in achieving organizational goals. The target for improving the performance of TB control programs so that the objectives of improving program performance are achieved become the central part of each organization. In this case, each private and government-owned health facility does not have a KTD PPM partnership model. In the PPM KTD, there must be a commitment from the leadership and all implementing staff in each health facility that will partner. In addition, in accordance with the WHO recommendation that to implement a TB control program using the DOTS strategy, the main thing must be a commitment from the government to ensure the sustainability of the program, then followed by activities to maintain the quality of diagnosis enforcement through laboratory examinations, provision of treatment 
according to standards, availability Essential OAT and standardized recording and reporting system [33].

Cooperation is the willingness of two organizations that agree to carry out joint activities and are written in a document. The collaboration document in the KTD PPM is an operational cooperation document between the health centre facilities and private health facilities to carry out TBDM collaboration activities which contain, who is involved, the goals and objectives, types of activities, the role of each partner written in the rights and obligations of each respectively, SOPs for each party, timeframe, process monitoring and conflict management if they occur, financial support, distribution of logistics and the presence of technical officers. The activities include conducting IEC, examination, determination of suspects, screening, treatment, monitoring of treatment, evaluation of treatment results, tracking of drop out cases, contact investigations, patient referrals and recording reports. In principle, a partnership is a cooperation agreement between two or more parties to achieve common goals. [31] said that the deal that occurred could be legally binding in written or formal form, or it could also be looser in oral or informal form. By having regulations combined with contracts, they can avoid unacceptable deviations and protect the public interest. Thus they are essential for the government in regulating PPPs. Then as stated by [13] because of the complexity, the partnership is a solution because only a single actor cannot do it, so there are two or more parties who work together to achieve a common goal. The TB control program is very complex. Several things have the potential to become problems, namely patient characteristics, diagnosis enforcement, monitoring of treatment regularity, laboratory tests, the potential for OAT resistance, and recovery. In this collaboration, [60] from the results of the implementation of his research, recommends the concept of a good partnership governance model which includes 3 (three) things, namely there is a centralized institution that has the authority, then technical implementation and understanding of the role of each party involved, as well as controlling the process so that it is achieved. desired result.

In cooperation with PPM KTD, partnership management must be carried out so that it can run well, which includes, there is an organization as an authority, in this case, the Pasuruan City Health Office, which private implementers carry out through a prior assessment by the City Health Office and Puskesmas, there is an operational cooperation script., then prepared resources, including human resources, where officers must be trained according to standards facilitated by the East Java Provincial Health Office, carry out SOPs, and monitor processes to measure success. Then periodic monitoring of the partnership process is carried out by the Monitoring Team consisting of academics and related professional organizations.

Communication is the sharing of information in the form of sending messages from the sender of the message to the recipient of the message. It must be carried out between officers who operationally carry out PPM KTD activities, in this case starting from TB and DM programmers at the Provincial Health Office, at the Pasuruan City level, at the Health Facilities level, either through telemedicine or groups. Online media. The existing SITT was developed by adding TB-DM collaboration information that includes recording and reporting what is available in the recording of DM patients being screened for TB. In addition, to communicate education and information to patients to be obedient in treatment and to the community to take precautions and check themselves if there are complaints that lead to TB or DM by providing facilitation to existing community organizations. In the era of advances in information technology, mobile communication can offer an alternative approach to the utilization of health services, especially in settings where a face-to-face course is difficult. [55] several types of mHealth interventions have been used to improve PPM in TB services, make appointments for treatment, support patient screening and case notification activities, and patient referral follow-up, monitoring $\mathrm{TB}$ treatment adherence, data management and training on TB for officers.

Trust from the research results of [3] found that faith is one factor that affects partnerships and communication, cooperation, and commitment as the dominant influencing factors. Trust is a belief from the implementing parties towards one another who can be relied on in fulfilling the obligations of the reciprocal relationship [29] To be able to carry out duties, there must be essential availability support. In the PPM KTD, materials must always be available, especially drugs and reagents for laboratory examinations, which are guaranteed and explicit who provides and distributes. This guarantee must be stated in the cooperation script in terms and obligations of each.

Another thing that adds to the trust is that in referring patients from the receiving health facility, they must send the news to the sending health facility so that the sending party can know the progress of the sent patient. Then the other most crucial thing is the trust of each party when referring patients. The medical actions taken by each party when they are going to direct must be trusted because this will significantly affect the following medical action taken by the recipient of the TB patient referral or DM, including mutual trust in terms of maintaining patient confidentiality. The study conducted by [34] stated that PPM is a proven and tested strategy to achieve the ultimate goal of TB globally. Conflicts of interest and mistrust between private practitioners and the public sector should be properly addressed to build sustainable linkages between sectors, regular monitoring and evaluation of the system and institutions are needed to meet the ultimate goals of TB. According to [10], trust helps the decision-making process, eliminates uncertainty and reduces complexity.

Quality of service is the service provided must be of quality in accordance with treatment standards and maintain the quality of laboratory examinations. In addition, the health facilities implementing PPM KTD owned by the government and the private sector must carry out activities according to technical instructions, and the officers involved have 
attended standardized training. From the findings of this study, the obstacle to implementing the national TB program is that the existing health facilities do not have SOPs, so that in training, it is essential to have additional material, namely the formulation of SOPs, it is hoped that after completing the training, participants already have SOPs according to their health facilities and can implement them according to standards. Then there is the assumption that private hospitals will provide social health services such as TB services that are not good, which has been refuted by the research results conducted by [15] private hospitals can provide quality health services and ease of access with the level of performance of social health services at least as good as public hospitals owned by the government. With PPM, to maintain the quality of TB treatment services in private health facilities due to limited access for TB patients to come to government-owned health facilities. In Indonesia, public and private health facilities for hospitals have been accredited, while only Puskesmas have been accredited outside hospitals. In this condition, when assessing health facilities that have not been accredited, an internal quality assessment must be carried out first. To improve the quality of service and patient safety of the Health Facilities, accreditation arrangements for Puskesmas, Pratama Clinics, doctors' independent practice are regulated in the Minister of Health Regulation of the Republic of Indonesia Number 46 of 2015 and handled explicitly in the Minister of Health of the Republic of Indonesia Number 35 of 2017. [32] stated that The main objective of government policy should be to encourage PPM, which ensures the availability of quality and affordable health services on a wide scale so that they systematically meet the needs of the population as a whole.

Dependency is the ability of a partner to influence another partner to do something they would not normally do. In PPM KTD, both Government and private parties will carry out a patient referral system which will create mutual dependence in carrying out coordinated care, especially for TB or DM with special conditions due to limited available resources. In the internal health facilities of the implementer, there is also dependence between the TB program manager and the DM program manager because, medically, there is a risk relationship between TB patients and DM. According to Van [1] the condition of interdependence, because actors, institutions and their associations originate from previous interactions, actors depend on other actors and institutions at one point in time, while institutions depend on actors for the production.

Adaptability is an organizational capacity to change demands, in which there is a change process with the aim of effectiveness [44]. With this KTD PPM, of course, there will be adjustments in the form of changes in the behaviour of officers, organizational structure, in the form of a collaboration team in each health facility, also changes in the rates in private health facilities and hospitals with BLU status. Specifically, it is regulated in the operational cooperation script for OAT that is obtained from the Government free of charge. If there is a subsidy from materials or reagents from the Government, then there is a tariff component that must be changed. The implementer's ability to adapt will influence the desired achievement. This is what [56] conveyed that innovation, networking, and complexity will allow organizations to adjust to enable them to operate as an adaptive system. Complex. And in this case, it takes the leadership role to do by keeping the organization in dynamic balance, which involves the simultaneous presence of disruptive elements (pushing towards chaos) and stabilizing elements (pushing towards order), which then together these elements occur, in the context of network interactions that create forces that trigger self-organization towards the emerging new order, namely adaptability. In partnership, the thing that must be considered is that the achievement of the goals of each actor individually requires activity by other actors, so that the principle of mutual adjustment is the main requirement.

Profit is intended by one or more parties who are equally aware of the critical aspects of doing a partnership, namely to provide mutual benefits and get more help to achieve their goals more optimally. According to [50], a mutualism partnership is an alliance of two or more parties who are equally aware of providing mutual benefits and getting more gifts so that they will be able to achieve their goals more optimally. This PPM KTD will be mutually beneficial for private and government health facilities. Income gains for the private sector include OAT subsidies distributed by the government, including laboratory infrastructure. There is a credit score for the doctor profession who carries out the national TB control program, then capacity building for its officers. In the PPM KTD, the private sector will get income from the examination and treatment of TB or DM patients from BPJS membership paid by the City Government. The City Government has accelerated the achievement of TB Elimination in its administrative area. According to [48], in TB services, the public and private sectors need to respect each other's uniqueness, communicate as equal partners, and share resources for a sustainable and mutually beneficial relationship. Another advantage for the private sector is that doctors, nurses, analysts and administrative officers have access to capacity building through training on TB with national standards and without paying.

The pattern of the PPM KTD partnership relationship becomes a non-profit business partnership based on public health services. Each implementer must make adjustments in terms of financial benefits, especially in private health facilities, to achieve the goal of TB elimination in Indonesia in 2030. According to [38] the business non-profit partnership is combining the relative strengths and resources of companies and non-profit organizations to reach solutions to social or environmental problems that the two institutions cannot handle independently.

Several things that must be input in the PPM KTD partnership method are priority programs, maintaining service quality, type and number of partnering health facilities, smooth TB-DM service activities, and the availability of essential logistics, supported by an integrated 
information system, as well as regulatory support, social support and financial support. Regulatory approval in the form of regional regulations regarding the involvement of all health facilities, including the private sector to be involved in the TB program, social support involving elements of community institutions in educating the community and conducting health screenings, then financing support to meet infrastructure facilities, especially the availability of drugs and the need for laboratory examinations, financing to meet the needs of the community. According to the work plan and funding for operations from the facilitation and monitoring team, all activities involve relevant professional organizations and academics.

Then in the process, the Partnership and collaboration model built in the KTD PPM contains the principles of Commitment, Cooperation, Trust, Communication, Service Quality, Dependence, Adaptability and Profit, will be able to contribute to the achievement of the two leading programs indicators so that it will accelerate achieve TB elimination in Indonesia (see Figure 6).

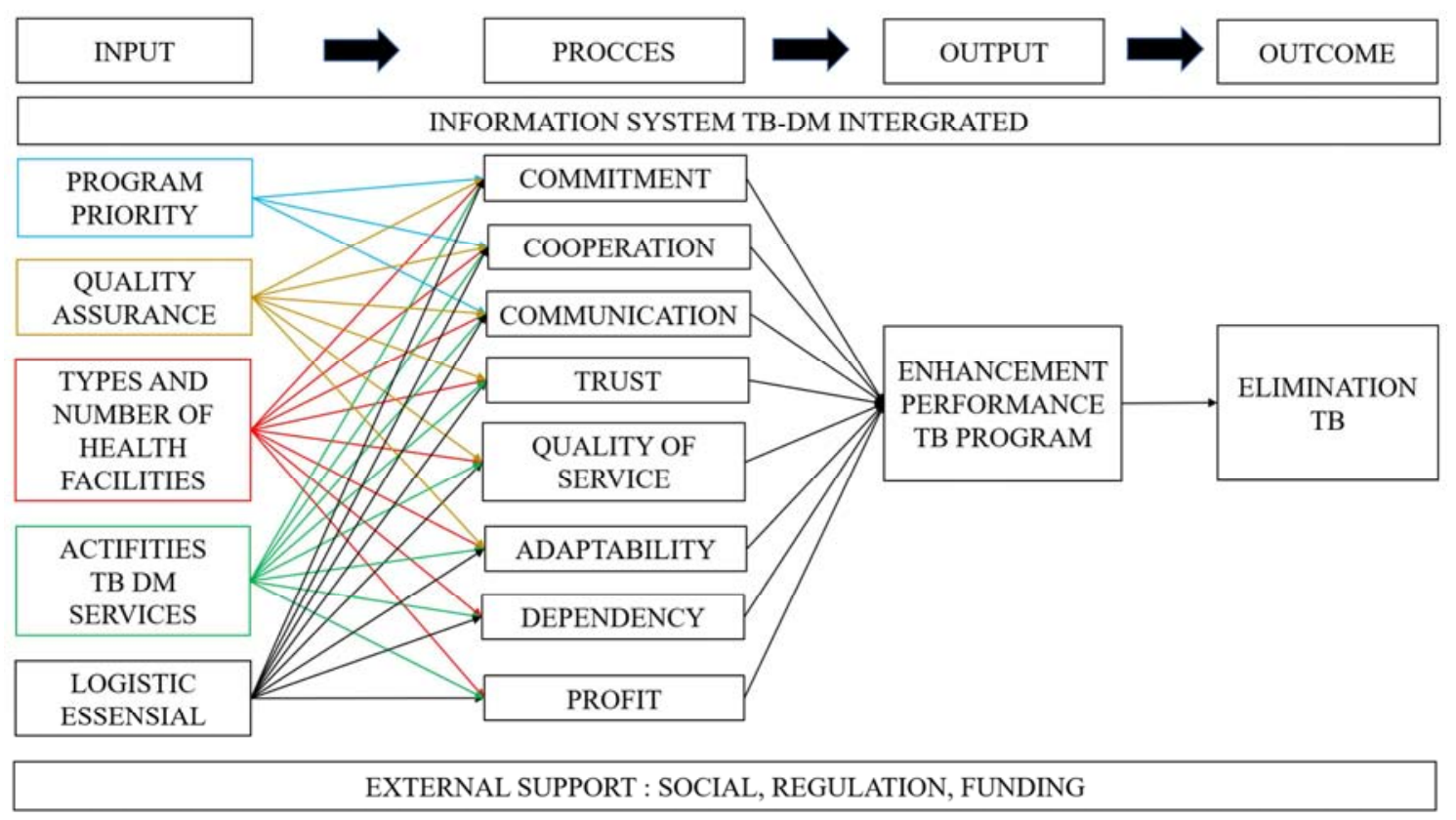

Figure 6. Frame work of Partnership Model of Public Private Mix Tuberculosis Diabetes Collaboration at Municipality Level.

The public policy of TB control through the PPM, KTD partnership method, is carried out for the government's desire so that TB elimination in Indonesia can be achieved in 2030, where the government involves the private sector, in this case, health facilities and the community through community organizations by conducting integrated programs. This is an implication of developing the theory of New Public Management and Good Governance in public administration, which encourages the implementation of good governance by involving three main components, namely the government, the private business world and the community.

PPM KTD will have implications for the collaboration of the TB program with the DM program in the form of activities for existing DM patients to have an initial examination towards TB, and vice versa for TB patients to be examined for $\mathrm{DM}$ to reduce the risk of not recovering. PPM KTB-DM certainly contributes to increasing the discovery rate and cure rate.

PPM KTD also makes changes to the partnership management which provides arrangements for the activities carried out, the resources used, there is an operational cooperation script and the output of this partnership must be measured periodically, the reporting recording system, and included as additional material in increasing the capacity of the implementer.

Partnerships and collaborations built-in PPM KTD have the principles of Commitment, Cooperation, Trust, Communication, Service Quality, Dependence, Adaptability, and Profit will contribute to the achievement of TB elimination in Indonesia.

PPM KTD can be appropriately implemented if there is political support in the form of local regulations regarding the involvement of all health facilities, including the private sector to be involved in the TB program, social support involving elements of community institutions in educating the community and conducting health screenings then supporting infrastructure facilities, especially the availability of drugs and examination needs. Laboratories, support for facilitation and monitoring teams involving related professional organizations and academics, and adequate financial support by program planning.

Based on the findings and discussions that have been described, a proposition related to the research findings on the PPM KTD partnership model in Pasuruan City is prepared as follows:

a. if the PPM KTD method is carried out with good governance, it will influence the realization of good cooperation between parties to increase the number of 
new TB patient discoveries, which is the main activity for achieving TB elimination in Indonesia which is targeted to be completed by 2030 .

b. if the PPM KTD Partnership model is carried out starting from the inputs that are fulfilled including, becoming priority programs, maintaining service quality, type and number of partnering health facilities, smooth TB-DM service activities, and availability of essential logistics, integrated information systems, social support, regulatory support, financing support with the $8 \mathrm{~K}$ process in the form of variables namely Commitment, Cooperation, Trust, Communication, Service Quality, Dependence, Adaptability and Profit will provide output in the format of performance results in the national TB program so that the outcome of TB elimination in Indonesia in 2030 can be achieved.

\section{Conclusion}

The PPM TB conducted in Pasuruan City has not provided a good performance program, where case finding rate of TB patients has not reached the target because monitoring process the partnership is not carried out, the existing principles of collaboration and governance have not all been implemented, and the contents of memo of understanding the operational TB program are incomplete and TB still not as a priority program. Principles of partnership that are carried out are only in the trust, equality, mutual benefit and risksharing.

PPM TDC as an effort to accelerate the achievement of TB Elimination which is the development of partnership PPM $\mathrm{TB}$ where the private sector is involved in a national TB control program collaboration with DM program is carried out by implementing the eight principles, Commitment, Cooperation, Communication, Quality of Service, Dependency, Adaptability and Profit.

Implementing the public policy of the National TB Control Program Partnership method: PPM KTD has developed involvement outside the government, namely involving the private sector and the community through community organizations.

The National TB Control Program with the PPM KTD partnership method provides additional main functions that the government must carry out, namely the community empowerment function from at least three existing main functions, namely the public service function, the development function (development function) and protection function.

In the policy implementation theory, what is related to the implementor variable is the characteristic variable of the implementing organization or institution. In this case, the health facilities, in particular, needs to be added to maintain service quality for patient safety.

The National Program for TB Control with the PPM TDC partnership method further clarifies the PPP theory where there is a combination of government resources with the private sector (profit and non-profit institutions). have to make adjustments in terms of financial benefits, especially in private health facilities in the form of non-profit service contracts to realize community goals, namely reducing the risk of people suffering from TB. This situation is expected in the TB elimination stage in Indonesia.

District/Municipality Governments that have implemented TB control programs with PPM TB must evaluate and develop the PPM TDC approach. Then for Governments that have not implemented the National TB program by involving private health facilities can immediately approach the PPM TDC. In evaluating the PPM TDC, it is carried out by an integrated monitoring team involving academics and professional organizations periodically. In carrying out capacity building for officers, it is necessary to add material about PPM TDC and formulate SOP according to the health facilities. The SOPs, which are part of the partnership management, are also included in the memo of understanding operational.

\section{References}

[1] Agarwal AK, Gupta G, Marskole P, Agarwal A. (2017). A study of the patients suffering from tuberculosis and tuberculosis-diabetes comorbidity in Revised National Tuberculosis Control Program Centers of Northern Madhya Pradesh, India. Indian J Endocr Metab, 21. Hal: 570-6.

[2] Amare, H., Gelaw, A., Anagaw, B., \& Gelaw, B. (2013). Smear positive pulmonary tuberculosis among diabetic patients at the Dessie referral hospital, Northeast Ethiopia. Infectious Diseases Of Poverty. 2 (1). https://doi.org/10.1186/2049-9957-2-6.

[3] Alam S. Asep, dan Hermawan, Heri, (2017), Faktor-faktor yang Mempengaruhi Hubumgan kemitraan antara Petani Budidaya Jamur Tiram dengan CV. Asa Agro Corporation, Journal Agroscience, Vol. 7 No. 1 Tahun 2017, Hal: 214219.

[4] Bovaird, Tony. (2014). Public-private partnerships: from contested concepts to prevalent practice Hal International Review of Administrative Sciences 70 (2). Hal: 200-215.

[5] Carey, Gemma. Sharon, Friel. (2015). Understanding The Role of Public Administration In Implementing Action On The Social Determinants Of Health And Health Inequities, International Journal of Health Policy and Management. Volume 4 Number 12. Hal: 795-798.

[6] Carnwell, Ros. Carson, Alex. (2005), Understanding, Partnerships and Collaboration in Effective Practice in Health and Social Care. a Partnership Appoach. Open University Press McGraw-Hill Education McGraw-Hill House Shoppenhangers Road Maidenhead Berkshire England.

[7] Cheung, K. Katherine. Masoud, Mirzaei. Stephen Leeder. (2010). Health Policy Analysis: A Tool to Evaluate in Policy Documents The Alignment Between Policy Statements and Intended Outcomes. Australian Health Review. Volume 34. Hal: 405-413.

[8] Creswell, John W. (2013). Qualitative inquiry and research design: choosing among five approache. SAGE. Los Angeles. 
[9] Delgado-Sánchez, G., García-García, L., Castellanos-Joya, M., Cruz-Hervert, P., Ferreyra-Reyes, L., \& Ferreira-Guerrero, E. et al. (2015). Association of Pulmonary Tuberculosis and Diabetes in Mexico: Analysis of the National Tuberculosis Registry 2000-2012. PLOS ONE, 10 (6). e0129312. https://doi.org/10.1371/journal.pone.0129312.

[10] De Vries. (2011), Some forms of trust. Information 2 (1). Hal: $1-16$.

[11] Drennan, Vari. Kate, Walters. Christina, Avgerinou. Benjamin, Gardner. Claire, Goodman. Rachel, Frost. Kalpa, Kharicha. Steve, Ilifffe. Jill, Manthrope (2018). Moving Upstream in Health Promoting Policies For Older People With Ealry Frailty in England? A Policy Analysis. Journal of Health Service Research \& Policy. Volume 23 Number 3. Hal: 168-175.

[12] Dwiyanto, Agus. (2015). Manajemen Pelayanan Publik. Gajah Mada University Press. Edisi Kedua.

[13] Eitan, Avri., Fischhendler, Itay, (2021), The social dimension of renewable energy storage in electricity markets: The role of partnerships, Energy Research \& Social Science, 76 (2021), Hal: 1-14.

[14] Fauziah, D. Fitri. Basyar, Masrul. Manaf, Asman. (2016). Insidensi Tuberkulosis Paru pada Pasien Diabetes Mellitus Tipe 2 di Ruang Rawat Inap Penyakit Dalam RSUP Dr. M. Djamil Padang. Jurnal Kesehatan Andalas. 2016: 5 (2). Hal: 349-354.

[15] Ferreira, D., \& Marques, R. (2021). Public-private partnerships in health care services: Do they outperform public hospitals regarding quality and access? Evidence from Portugal. Socio-Economic Planning Sciences. 73, 100798. https://doi.org/10.1016/j.seps.2020.100798.

[16] Futter-Puati, Debbie. Bryder, Linda. Park, Julie. Littleton, Judith. Herda, Phyllis. (2013). Partnerships for health: Decimating tuberculosis in the Cook Islands, 1920-1975. Health \& Place 25. Hal: 10-18.

[17] Global tuberculosis report. (2017). World Health Organization 2017.

[18] Haryono, Nanang (2012), Jejaring Untuk Membangun Kolaborasi Sektor Publik, Jejaring Administrasi Publik. Th IV. Nomor 1, Januari-Juni 2012, hal: 47-53.

[19] https://pasuruankota.go.id/profil-pasuruan/.

[20] https://tbindonesia.or.id/berita/3-arahan-presiden-soalpercepatan- pengurangan- tuberkulosis. (2020).

[21] IHME (2020), Institute Health Metric, $\mathrm{http} / / / \mathrm{www} \cdot h$ halthdata.org/indonesia.

[22] Kementerian Kesehatan RI. (2015), Peraturan Menteri Kesehatan Nomor 46 Tahun 2015 tentang Akreditasi Puskesmas, Klinik Pratama, Tempat Praktik Mandiri Dokter, dan Tempat Praktik Mandiri Dokter Gigi.

[23] Kementerian Kesehatan RI. (2016), Peraturan Menteri Kesehatan Republik Indonesia Nomor 67 tahun 2016 tentang Penanggulangan Tuberkulosis.

[24] Kementerian Kesehatan RI. (2017), Peraturan Menteri Kesehatan Republik Indonesia nomor 34 tahun 2017 tentang Akreditasi Rumah Sakit.

[25] Kementerian Kesehatan RI. (2018) Infodatin, Pusat Data dan Informasi Kementerian Kesehatan RI, 2018.
[26] Keban, T. Yeremias. (2019). Enam Dimensi Strategis Administrasi Publik Konsep, Teori dan Isu. Penerbit Gava Media. Edisi Revisi.

[27] Kumar V, Abbas AK, Fausto N, Mitchell RN., (2007). Robbins Basic Pathology (edisi ke-8th). Saunders Elsevier, hal: 516522 .

[28] Lei, X., Liu, Q., Escobar, E., Philogene, J., Zhu, H., Wang, Y., \& Tang, S. (2015). Public-private mix for tuberculosis care and control: a systematic review. International Journal Of Infectious Diseases. 20-32. https://doi.org/10.1016/j.ijid.2015.02.015.

[29] Lendra, et. al. (2006). Tingkat Kepercayaan dalam Hubungan Kemitraan antara Kontraktor dan Subkontraktor, Civil Engineering Dimension, Vol. 8, No. 2, 55-62, September 2006, Hal: 55-62.

[30] Lonnroth, Knut. Gojka, Roglic. Anthony, D. Harries. (2014). Improving tubercolosis prevention and care through addressing the global diabetes epidemic: from evidence to policy and practice. Diabtes-Endocrinology Volume 2. Hal: 730-739.

[31] Marques, C. R., Sara. Ferreirab, A. F., Fernando., MeidutèKavaliauskiened, Leva. Banaitis, Audrius. (2018). Classifying urban residential areas based on their exposure to crime: A constructivist approach. Sustainable Cities and Society 39 . Hal: 418-429.

[32] McGuire, Michael. (2006). Collaborative Public Management: Assessing What We Know and How We Know It Collaborative Public Management, Public Administration Review, December 2006. Hal: 33-43.

[33] Medhat F. Negm, Gehan F. Al mehy, Tahany M. Ali, Safwa S. Abd Elfadi, 2016, Tuberculosis situation in Ismailia governorate (2002-2012) before and after Direct Observed Therapy Short Course Strategy (DOTS), Egyptian Journal of Chest Diseases and Tuberculosis, 65, Hal: 211-217.

[34] Menberu, Melat. Kar, Sonali. Behera Ranjan Manas. (2021). Review on public private mix TB control strategy in India. India Journal of Tuberculosis, Available online 15 July 2021.

[35] Meyer dan Herscovitch, 2001. Commitment in the Workplace: Toward a General Model, London: Blackwell Scientific Publications, Hal: 98.

[36] Moleong, J., Lexy. (2010). Metode Penelitian Kualitatif. Bandung: Remaja Rosda Karya.

[37] Mulyadi, Deddy, (2018). Studi Kebijakan Publik dan Pelayanan Publik. Penerbit Alfabeta, hal 47, 83, 89, 117.

[38] Murthy, Rama, Sudhir. Roll, Kate. Colin-Jones, Alastair. (2021). Ending business-non-profit partnerships: The spinout of social enterprises. Scandinavian Journal of Management. 37. Hal: 1-13.

[39] Mustafa, T., Abdul. (2017). Kemitraan Dalam Pelayanan Publik, Calpulis, Yogyakarta.

[40] Nugroho, Riant, (2018). Public Policy. PT Gramedia Jakarta, 725-778.

[41] Pal, Rahul. Ansari, A. Moiz. Hameed, Saif. Fatima, Zeeshan (2016). Diabetes Mellitus as Hub for Tuberculosis Infection: A Snapshot. International Journal of Chronic Diseases. Volume 2016. Hal: 1-7. 
[42] Porter, Lyman W., and Steers R. M. (1973), Organizational, Work, and Personal Factors in Employee Turn Over and Absenteeism. Psychological Bulletin. 80 (2): 151-176, Hal: 520.

[43] Rohman, Hendra. (2018). Kasus Tuberkolulosis dengan Riwayat Diabettes Mellitus di Wilayah Prevalensi Tinggi Diabettes Mellitus. Jurnal Manajemen Informasi Kesehatan Indonesia. Volume 6 Nomor 2. Hal: 149-158.

[44] Rico, Ramo'n. Gibson, B., Cristina. Sa'nchez-Manzanares, Miriam. Clark A., Mark. (2018), Building team effectiveness through adaptation: Team knowledge and implicit and explicit coordination, Organizational Psychology Review. Hal: 1-28.

[45] Sabaruddin, Abdul. (2015). Manajemen Kolaborasi dalm Pelayanan Publik, Toeri, Konsep dan Aplikasi, Graha Ilmu, Yogyakarta, hal, 25-26.

[46] Santana K Septian. (2007). Metode Penelitian Kualitatif. Yayasan Obor Indonesia Anggota IKAPI DKI Jakarta. Hal: 82

[47] Savas, E. S. (2000). Privatization and Public-Private Partnership, Baruch College City University of New YorkLondon.

[48] Sherpa, James. Yadav, Rajendra-Prasad. (2021). Perceptions of the Private Sector for Creating Effective Public-Private Partnerships against Tuberculosis in Metro Manila, Philippines. Am J Trop Med Hyg. 2019 Sep; 101 (3). Hal: 498-501.

[49] Stallworthy, G., Dias, H., \& Pai, M. (2020). Quality of tuberculosis care in the private health sector. Journal Of Clinical Tuberculosis And Other Mycobacterial Diseases. 20, 100171. https://doi.org/10.1016/j.jctube. 2020.100171.

[50] Sulistiyani, T., Ambar. (2017). Kemitraan dan Model-model Pemberdayaan. Penerbit Gava Media.

[51] Thapa, B., Paudel, R., Thapa, P., Shrestha, A., \& Poudyal, A. (2016). Prevalence of Diabetes among Tuberculosis Patients and Associated Risk Factors in Kathmandu Valley. SAARC Journal Of Tuberculosis, Lung Diseases And HIV/AIDS. 12 (2), 20-27. https://doi.org/10.3126/saarctb.v12i2.15951.

[52] Tiemersma, W., Edine. Hafidz, Firdaus. (2014). Costs faced by (multidrug resistant) tuberculosis patients during diagnosis and treatment Report from a pilot study in Indonesia. KNCV Tuberculosis Foundation.

[53] Tobing, Sulianti K., L., Diana. (2009). Pengaruh Komitmen Organisasional dan Kepuasan Kerja Terhadap Kinerja Karyawan PT. Perkebunan Nusantara III di Sumatera Utara, Jurnal Manajemen dan Kewirausahaan, Vol.11, No. 1, Maret 2009, Hal: 31-37.
[54] Toyib, Yusid. Nugroho, Riant (2018). Transformasi Public Private Partnership Indonesia. PT Elex Media Komputindo, Jakarta.

[55] Tumuhimbise, Wilson. Musiimenta, Angella. (2021). A review of mobile health interventions for public private mix in tuberculosis care. Internet Interventions 25. Hal: 1-13.

[56] Uhl-Biena, Mary. Arena, Michael. (2018). Leadership for organizational adaptability: A theoretical synthesis and integrative framework. The Leadership Quarterly 29. Hal: 89104.

[57] Utarini, Adi. (2019). Penelitian Kualitatif Dalam Pelayanan Kesehatan. Gadjah Mada University Press.

[58] Van Assche, K., Beunen, R., Duineveld, M. (2016). An overview of EGT's main concepts. In: Beunen, R., Van Assche, $K$., Dunineveld, M. (Eds), Evolutionary Governance Theory. Springer, New York, Hal: 19-32.

[59] Van Meter, D., \& Van Horn, C. (1975). The Policy Implementation Process. Administration \& Society. 6 (4), 445488. doi: 10.1177/009539977500600404.

[60] Wang, N., Gong, Z., Liu, Y., \& Thomson, C. (2020). The influence of governance on the implementation of PublicPrivate Partnerships in the United Kingdom and China: A systematic comparison. Utilities Policy. 64. Hal: 101059. doi: 10.1016/j.jup.2020.101059.

[61] Widjanarko, Bagoes. Prabamurti, N., Priyadi. Widayat, Edi. (2006), Pengaruh Karakteristik, Pengetahuan dan Sikap Petugas Pemegang Program Tuberkulosis Paru Puskesmas Terhadap Penemuan Suspek TB Paru Di Kabupaten Blora, Jurnal Promosi Kesehatan Indonesia. Vol. 1. No. 1. Januari 2006. Hal: 41-52.

[62] World Health Organization (2021). About the Public Private Mix (PPM) initiative. https://www.who.int/tb/areas-ofwork/engaging-care-providers/public-private-mix/about/en/.

[63] Xenos., Nektarious., Constantopaulos, Yfantopoulus, (2015). Two stage hospital efficiency analysis including qualitative evidance: Agreek case. Journal of Hospital Administration., Volume 5 No 3. Hal: 1-9.

[64] Yorke, E., Atiase, Y., Akpalu, J., Sarfo-Kantanka, O., Boima, V., \& Dey, I. (2017). The Bidirectional Relationship between Tuberculosis and Diabetes. Tuberculosis Research And Treatment, 2017, 1-6. https://doi.org/10.1155/2017/1702578.

[65] Zheng, C., Hu, M., \& Gao, F. (2017), Diabetes and pulmonary tuberculosis: a global overview with special focus on the situation in Asian countries with high TB-DM burden. Global Health Action, $10 \quad 1264702$. https://doi.org/10.1080/16549716.2016.1264702. 